\title{
CÂTEVA DATE DESPRE CONFERINȚELE LUI IOAN ANDRIEŞESCU LA RADIOUL PUBLIC
}

CĂTĂLIN I. NICOLAE

\section{REZUMAT:}

Modesta noastră contribuție își propune să aducă la lumină câteva documente inedite aparținând arheologului Ioan Andrieșescu (1888-1944). Unul dintre cei mai importanți arheologi români ai perioadei interbelice, Andrieșescu s-a alăturat unei pleiade de arheologi ce au conferențiat la radioul public. Textele acestor conferințe, documente interesante pentru istoria disciplinei noastre, păstrate parțial, sunt prezentate mai jos.

\section{ABSTRACT: FEW REMARKS REGARDING SOME UNPUBLISHED RADIO CONFERENCES OF IOAN ANDRIEŞESCU}

We are presenting here the unpublished texts of some conferences delivered by the Romanian archaeologist Ioan Andrieșescu (1888-1944) at the National Radio. One of the most important archaeologists of the inter-war era, a well-known professor of archaeology and prehistory, Andrieșescu joined a handful of other profesionals in delivering a series of conferences on a wide range of subjects related to the history of archaeology, personalities of archaeology, prehistoric art and current archaeological research in Romania.

CUVINTE CHEIE: Andrieșescu, radio, artă, Dacia, Odobescu.

KEYWORDS: Andrieșescu, radio, art, Dacia, Odobescu.

\section{Despre începuturile radioului în România}

Sfârșitul primului război mondial și crearea României Mari au deschis calea progresului și au stimulat racordarea la valorile europeene în toate sectoarele societății românești de după 1918. Perioada interbelică se remarcă nu numai printr-o puternică efervescență culturală, dar și prin diversificarea căilor de diseminare a conținutului cultural și educațional către populație. În cadrul acestei vaste transformări și evoluții culturale, la sfârșitul anului 1927, se pun bazele legale ale constituirii primei societăţi naționale de radio din România, în decembrie 1927 Consiliul de Miniștri declarând constituită „Societatea de Difuziune Radiotelefonică din România”. Societatea, cu capital majoritar de stat, va fi înregistrată oficial la tribunal în martie 1928.

În ziua de joi, 1 noiembrie 1928, la ora 17, se difuzează oficial prima emisiune a postului "Radio România".

La 3 martie 1930 este inaugurată emisiunea "Universitatea Radio”, cu prelegerea lui Dimitrie Gusti „Menirea Radiofoniei Româneşti“, emisiune în cadrul căreia vor fi transmise numeroase conferințe ținute de personalităţi ale intelectualitații românești din perioada interbelică, inclusiv istorici și arheologi .

În data de 4 aprilie 1936 “Societatea de Difuziune Radiotelefonică" devine "Societatea Română de Radiodifuziune”, nume sub care activează şi astăzi radioul public(SRR).

La sfârşitul celui de al doilea război mondial, în august 1944 bombardamentele germane distrug studiourile şi sediul central al Radiodifuziunii din str. Gen. Berthelot nr. 60. Odată cu încheierea războiului începe o nouă epocă pentru SRR, în data de 17 septembrie fiind emis un decret-lege de epurare a administraţiei publice de ,elementele fasciste“, iar câteva zile mai târziu SRR este trecută în subordinea Comisiei Militare Aliate Sovietice'1.

\footnotetext{
$\overline{1}$ Denize 1998, passim.
} 
Arhiva SRR a supraviețuit avatarurile războiului și cenzurii, fiind azi o sursă extraordinară de informații pentru cercetători. În ceea ce privește arhiva scrisă, practica depunerii manuscrisului conferinței a apărut destul de devreme, încă din 1932, când "Regulamentul programului vorbit" prevedea păstrarea textelor celor mai reprezentative conferințe și publicarea lor într-o revistă. Chiar dacă revista nu a mai apărut, manuscrisele conferințelor s-au păstrat în mare parte ${ }^{2}$.

\section{Arheologi la Radio}

Primele conferințe dedicate arheologiei sunt transmise începând cu anul 1930, aproape toate în cadrul emisiunii „Universitatea Radio”. Debutează acum în radiofonie Radu Vulpe, Ion Nestor, Vladimir Dumitrescu, Dinu V. Rosetti, urmați în 1931 de Ioan Andrieșescu și Constantin S. Nicolaescu-Plopșor. Începând cu 1932 numărul arheologilor ce conferențiază la radioul public crește - apar Scarlat Lambrino, Constantin Daicoviciu, preotul Constantin Matasă, Paul Nicorescu, Grigore Florescu, Dionisie M. Pippidi, Emil Condurachi, Dumitru Tudor şi alții - la fel ca şi numărul conferințelor ce tratează subiecte de arheologie ${ }^{3}$.

În rândurile ce urmează vom prezenta textele, inedite, mai multor conferințe radiofonice aparţinând lui Ioan Andrieșescu (1888-1944). Din cele 12 conferințe prezentate în perioada 1931-1935 s-au păstrat textele integrale a cinci dintre ele.

Născut la Iași în mai 1888 Ioan Andrieșescu urmează cursuruile Facultății de Litere și Filosofie în perioada 1907 1911, specializarea istorie, având ca profesori, printre alții, pe A.D. Xenopol și Teohari Antonescu. În timpul facultății întreprinde mai multe călătorii de studii la Florența și Roma (1910), Atena, Constantinopol, Belgrad, Viena, Budapesta (1911), unde vizitează monumente și studiază în bibliotecile institutelor franceze și germane. După mai multe stagii de documentare în Germania își susține în 1912 teza de doctorat, intitulată sugestiv „Contribuție la Dacia înainte de Romani”’4. Era prima sinteză de preistorie din spaţiul românesc, și aşa cum bine sugerează titlul, intenția autorului era de a adăuga informație la ceea ce scrisese Gr. Tocilescu în magistrala sa lucrare din $1880^{5}$. După susținerea doctoratului pleacă din nou în Germania unde se înscrie la cursurile universitătii din Berlin, audiind cursurile profesorilor Gustaf Kossinna, Eduard Meyer, Ulrich von Wilamowitz-Moellendorff, Hermann Dessau, Kurt Regling și Hubert Schimdt ${ }^{6}$. Pentru a se întreține în această perioadă activează și ca funcționar (19131915) la Legația României din Berlin, numit de Titu Maiorescu. Revenit în țară, datorită problemelor generate de primul război mondial, este adus de Vasile Pârvan la Muzeul Naţional de Antichităţi (MNA), pe postul de asistent-șef, în 1915, fiind promovat ulterior conservator (1916) şi subdirector (1919). După sfârşitul primului război mondial începe perioada cea mai fertilă din parcursul profesional al lui Andrieșescu, activitatea la MNA fiind dublată de cea de la Universitatea din București. În 1920 devine docent în arheologie preistorică ${ }^{7}$, iar în 1923 conferențiar, urmând ca după dispariția lui Pârvan să ajungă profesor universitar. În studiile sale Andrieșescu abordează și deschide noi domenii de interes - perioada neolitică pe teritoriul românesc, depozitele de epoca bronzului, civilizaţia geto-dacică în Muntenia sau necropolele de la începutul epocii migrațiilor. Alte contribuții privesc istoria arheologiei, românești sau europeene. Andrieșescu scoate preistoria românească din perioada sa romantică și îi indică direcția de dezvoltare ca știință. Redactează manuale pentru studenți, organizează congrese și expoziții, conferențiază pentru un public divers. Depune și o susţinută activitate de teren, prin săpături arheologice efectuate, singur sau în colaborare, la: Agighiol, Coțofeni, Fedeleşeni, Oinac, Ostrovu Corbului, Piscul Crăsani, Poiana-Coțofenești, Popești-Novaci, Sălcuţa, Sărata Monteoru, Sultana, Zimnicea, o parte din ele rămase nevalorificate prin publicare din păcate.

În 1931 Ioan Andrieșescu era aşadar una din cele mai importante figuri a peisajului arheologic românesc. Director al MNA, profesor de arheologie la Facultatea de Litere și Filosofie a Universității din București, director al Seminarului de Arheologie preistorică şi editor al revistei sale, Revista de Preistorie și Antichități Naționale(RPAN), era fără îndoială cea mai importantă figură a lumii arheologice din capitală, fără însă a avea anvergura sau prestigiul predecesorului său, Vasile Pârvan, decedat în 1927. Situarea aceasta, chiar la câțiva ani de la moartea lui Pârvan, în umbra acestuia, este poate subliniată și de faptul că Radu Vulpe, fost elev al lui Pârvan, este primul arheolog

\footnotetext{
2 Nicolae 2011, 67-68.

3 Mușețeanu 1998, passim.

4 Andrieșescu 1912.

5 Tocilescu 1880 - Dacia înainte de romani. Cercetare asupra poporului care a locuit Țările Române de la stânga Dunării, mai înainte de conquista acestor țări de contra Imperiului Traian, cu 38 de stampe, 4 hărți din care 2 cromolitografii și 171 figuri în text, București, Tipografia Academiei Române, 1880, 594 p.

6 Petrescu-Dâmbovița 2005, passim.

7 Tot Pârvan îl susține și aici, dar și Nicolae Iorga.
} 
invitat să conferențieze la tribuna radioului, în 1930. Radu Vulpe este și arheologul cu cele mai multe prezențe la radioul public în perioada interbelică, cu nu mai puțin de 76 de conferințe ${ }^{8}$. El este urmat, la mare distanţă, de Paul Nicorescu și Dinu V. Rosetti, cu câte 13, și apoi de Andrieșescu, cu $12^{9}$. Nu știm de ce Andrieșescu are atât de puține conferințe, este însă cert că ele încetează în 1935, probabil după demisia sa de la conducerea MNA. Temele abordate erau diverse, după cum puteam vedea și din lista de mai jos:

1. Din trecutul nostru străvechi (I), 20 martie 1931, ora 19,00 - text pierdut;

2. Xenopol, 4 aprilie 1931, ora 19,40 - text pierdut;

3. Din trecutul nostru străvechi (II), 10 mai 1931, ora 19,00 - text pierdut;

4. Arta primitivă, 22 mai 1931, ora 19,00 - text pierdut;

5. Problemele muzeelor la noi (I), 26 iunie 1931, ora 20,40 - text pierdut;

6. Problemele muzeelor la noi (II), 13 iulie 1931, ora 21,30 - text pierdut;

7. Începuturile străvechi ale istoriei, 21 februarie 1932, ora 15,45 - text pierdut;

8. Noui descoperiri arheologice, 5 septembrie 1933, ora 20,40 - Arhiva S.R.R., dosar nr. 14/1933, 8 file;

9. Artele în timpurile preistorice la noi (I), 2 august 1934, ora 20,30 - Arhiva S.R.R., dosar nr. 11/1934, 8 file;

10. Artele în timpurile preistorice la noi (II), 23 august 1934, ora 20,15 - Arhiva S.R.R., dosar nr. 11/1934, 6 file;

11. Arheologul Teohari Antonescu, 25 ani de la moartea sa, 7 noiembrie 1935, ora 19,00 - Arhiva S.R.R., dosar nr. 13/1935, 7 file;

12. Un căutător de aur: Heinrich Schliemann, 27 decembrie 1935, ora 20,15 - Arhiva S.R.R., dosar nr. 11/1936, 9 file.

O trecere în revistă a subiectelor conferințelor ne arată predilecția lui Andrieșescu pentru câteva teme mari - arta preistorică, muzeele, preistoria, personalități ale istorie și arheologiei - toate teme regăsite și în opera publicată, nu foarte numeroasă.

Deși textul conferinței despre Xenopol nu s-a păstrat, intuim direcția sa - una apreciativă și de recunoștință, Andrieșescu audiind cursurile lui Xenopol la Iași, acesta din urmă fiind și membru în comisia de examinare la susținerea doctoratului. În același ton sunt redactate și conferințele despre Teohari Antonescu, fost și el profesor la Iași în timpul studenției lui Andrieșescu, și Schliemann, aparţinând arheologiei germane de care era foarte legat ${ }^{10}$.

Recunoștința și admirația față de Teohari Antonescu nu se opresc la această conferință radiofonică - Andrieșescu publică mai multe articole despre viața și opera lui Teohari Antonescu ${ }^{11}$ și este cu siguranță cel care a promovat atribuirea numelui acestuia noului muzeu de istorie din Giurgiu (locul nașterii lui Antonescu).

Teohari Antonescu este unul din arheologii căruia îi sunt dedicate mai multe conferințe radiofonice, dar dacă Andrieșescu face o biografie elogioasă și se preocupă mai puțin de opera științifică a lui Antonescu, într-o altă conferință, Emil Condurachi ${ }^{12}$ nu ezită să critice masiv teoriile acestuia cu privire la columna traiană, monumentul de la Adamclisi sau cetatea Sarmisegetusa. Singurul acord între cele două abordări privește cercetările de teren ale lui Teohari Antonescu pentru identificarea principalelor puncte de desfăşurare ale celor două războaie dintre daci și romani, unanim apreciate.

Singurul arheolog străin prezentat la radioul public, Schliemann, beneficiază din păcate doar de o preluare masivă din biografia scrisă de Emil Ludwig ${ }^{13}$ și nimic mai mult, Andrieșescu, în mod surprinzător, nevalorificând nimic din cunoștințele sale privitoare la arheologia germană.

Revenind însă la prima conferință pentru care avem textul păstrat, remarcăm claritatea și bogăția detaliilor.

\footnotetext{
8 Pregătim un volum grupând conferințele radiofonice aparținând lui Radu Vulpe.

9 Nicolae 2011, 68.

${ }^{10}$ A fost membru al Gesellschaft für Deutsche Vorgeschichte și al Berliner Gesellschaft für Anthropologie, Ethnologie und Urgeschichte, printre altele.

${ }^{11}$ Andrieșescu 1910; Andrieșescu 1920; Andrieșescu 1935.

${ }^{12}$ Condurachi 1943.

${ }^{13}$ Ludwig 1932.
} 
Conferința se vrea o prezentare a ultimului număr al revistei Dacia(vol. I) ${ }^{14}$ dar reușește să fie o scurtă trecere în revistă a istoriei arheologiei românești și în special a rolului MNA în dezvoltarea acesteia. Andrieșescu prezintă clar, succint, pozitiv cercetările arheologice realizate de membri MNA în perioada 1927-1930 pe teritoriul României. Surprinde încrederea lui Andrieșescu în viitoarea înființare a unui Institut arheologic (atât de dorit de Pârvan) dar și admiterea faptului că ea nu se va întâmpla prea curând.

Arta preistorică este o precupare recurentă la Andrieșescu și nu este surprinzător că textul celor două conferințe despre această temă, mult îmbuntățit și îmbogățit cu o ilustrație foarte bună(majoritar fotografică), va fi publicat în 1939 în splendida revistă Arta și Tehnica grafică ${ }^{15}$. O privire rapidă asupra celor două texte relevă solida pregătire a lui Andrieșescu, lecturile la zi din literatura europeeană dar și capacitatea de sinteză și analiză. În cuvinte bine alese, fără a sufoca auditoriul, Andrieșescu trece elegant de la teoriile lui Odobescu la marele preistorician Herbert Kühn şi de la viziunea asupra sculpturii aparținând lui Rodin la aprecierile lui Romain Rolland despre rolul artei. Este fără îndoială mediul în care dă cea mai bună dovadă a solidei sale pregătiri și este păcat că o moarte prematură dar şi alte considerente au făcut ca opera sa să nu fie mult mai importantă pentru arheologia preistorică românească. În arhiva documentară a Institutului de Arheologie „Vasile Pârvan” se păstrează o altă copie a manuscrisului primei conferinţe despre arta preistorică, fiind cel mai probabil exemplarul lui Andrieșescu, datat chiar de către autor - 2 august 1934 (Fig. 1).

Deși prezentate sumar în contribuția noastră, considerăm că publicarea unor astfel de documente este foarte importantă pentru o mai bună înţelegere a evoluției și istoriei disciplinei noastre, arheologia. Aflată la maturitate, arheologia românească este încă lipsită de o istorie proprie, sinteză la a cărei bază trebuie să stea, fără îndoială, pe lângă cercetările publicate și documentele din arhive. Într-un studiu ${ }^{16}$ ce părea să deschidă o promițătoare serie de texte ${ }^{17}$ despre istoria arheologiei românești, publicat în anul 2000, Dragomir Popovici amintea de fragilitatea cercetării preistorice românești la începutul sec. XX. Aflaţi, 100 de ani mai târziu, la începutul sec. XXI cred că avem datoria să contribuim la soliditatea științei noastre, înțelegând și asumându-ne istoria ei.

Redăm în rândurile ce urmează textul celor cinci conferințe. Toate textele sunt scrise la mașină ${ }^{18}$ și adnotate de către Andrieșescu. O parte sunt semnate și datate de el și sunt ștampilate cu ștampila Radiodifuziunii (Fig. 2). Am păstrat grafia originală, precum și sublinierile din text aparţinând lui Andrieșescu.

\section{Mulțumiri}

Redactarea acestui material nu ar fi fost posibilă fără ajutorul neprețuit și sprijinul constant al colegilor din colectivul Direcției Arhiva scrisă din cadrul Societății Române de Radiodifuziune cărora le mulțumim și pe această cale. Lavinia Vișan și Raluca Nicolae au oferit un prețios ajutor în transcrierea textelor, le mulțumesc și pe această cale. Profesorul Mircea Babeș a fost cel care mi-a sugerat cercetarea personalităţii lui Ioan Andrieșescu, îi sunt recunoscător. Cătălin Bem, Andrei Asăndulesei și Bogdan Venedict m-au sprijinit în cercetarea documentelor din arhivele ieșene privitoare la Andrieșescu, le sunt îndatorat. Roxana Dobrescu mi-a facilitat accesul la arhiva documentară a Institutului de Arheologie „Vasile Pârvan”, îi mulțumesc încă o dată.

Last, but not least, gândurile noastre recunoscătoare se îndreaptă către Profesorul Dragomir Nicolae Popovici, prea devreme plecat dintre noi, care a încurajat constant demersul nostru, călăuzindu-ne pașii prin arhive și oferindu-ne, cu generozitatea-i caracteristică, documentația sa cu privire la Andrieșescu.

\footnotetext{
${ }_{14}^{14}$ Volumul II nu avea să mai apară niciodată, fiind publicat doar un pliant de prezentare al acestuia.

15 Andrieșescu 1939.

${ }^{16}$ Popovici 2000, 19

${ }^{17}$ Din păcate doar primul fascicul al seriei a fost publicat.

${ }^{18}$ Numărul mare de documente din arhiva Andrieșescu scrise la mașină ne sugerează faptul că acesta deținea una.
} 


\section{$-8-$}

anevo1e să se exprime in arh1tectură: arh1tectura cere ban1, ea re-

clamă constructun1; bună starea, incredere In viltor. Artele plastice In genere au nevole pentru ca să Inflorească, de lux ș1 plăcerilune1 clase rafinate, un oarecare echilibru de c1vilizație. Dar când condiłł1le materiale ajung ma1 a păsătoare, când viața devine aspră, săracă, hấţu1tă de grij1, cểnd 1̂ este 1ntersiz să se desvoltăin afară, ea se Intoarce asupra el 1nsăşi ş1 eterna e1 nevole de fer1c1re o face să găsească alte drumuri artist1ce; frumusețea se transformă; ea devine inter1oară, ea se refugiază în arteIe profunde: poezia, muzica. Ba nu moare. Nu există nic1 moarte nic1 renașterea uman1tăț11. Lum1na nu 1ncetează n1c1odată să arda; $\theta a$ se deplasează numa1, merge dêla o artá la alta ş1 dela un popor la altul. Dacé nu veţ1 studia decât una din ele,veț1 găsi in 1storle inreruperı, sincope, ĉând inıma incetează de a bate. Pe când, dacă veţ contempla ansamblul tuturor artelor, veţ1 sımţı cum curge eternitatea vieţ11".-

Transpuneţ1 vă rog ş1 aceste cons1deraţiunı adâne simţ1te ş1 adevărate 1 in indepărtatul trecut de Inceputur1 \$̦1 trecerea umanităţi dela preistor1e la vremur1le 1stor1ce. Intre"natúa techn1eă \$1 artä." cum clar și convingator face aproplerile \$̧1 deosebir1le intre ele, un cunoscut esteticean al nostru, avem elementele de bază pentru prezentarea ma1 departe, după puter1le noastre, 62 de an 1 dela Alexandru Odobescu, a artelor din timpurile preistorice la no1..

$2 \operatorname{ting} \cdot i 934$

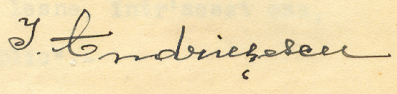

Figura 1. Ultima pagină a manuscrisului conferinței Artele în timpurile preistorice la noi (I), Institutul de Arheologie „Vasile Pârvan”, Arhiva documentară, Fond Andrieșescu.

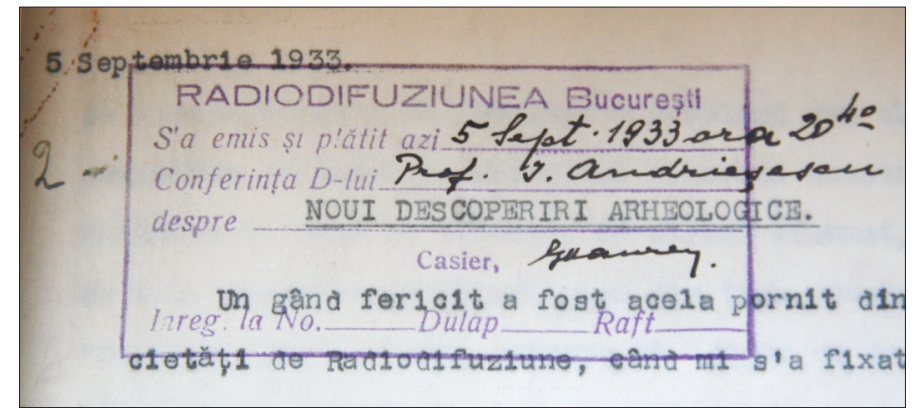

Figura 2. Ștampila Radiodifuziunii pe prima pagină a manuscrisului conferinței Noui descoperiri arheologice, Arhiva SRR, dosar nr. 14/1933, fila 1. 


\section{Conferințele radiofonice}

\section{Noui descoperiri arheologice}

Un gând fericit a fost acela pornit din Comitetul Onoratei Societăţi de Radiodifuziune, când mi s-a fixat pentru a vorbi astă seară despre „Noi descoperiri arheologice”.

Aceasta se potriveşte foarte bine cu un fapt care, fie-mi permis a o spune chiar eu, îşi va avea însemnătatea sa în evoluţia studiilor arheologice la noi. Este reapariţia revistei „Dacia”: „Recherches et découvertes archéologiques en Roumanie", întemeiată de regretatul Vasile Pârvan în 1927, acum ajunsă la volumele III şi IV, partea I cuprinzând în peste 600 de pagini cu mai mult de 800 de clişee, un număr de 26 de studii, referitoare exclusiv la descoperirile şi antichităţile noastre, preistorice, greco-romane şi barbare-medievale.

Despre aceste descoperiri şi cercetări voi vorbi deci astăzi, deşi, trebuie să mărturisesc, cu mai multă libertate de spirit aş putea vorbi despre cele mai noi descoperiri arheologice străine, pentru care se găsesc ample dări de seamă nu numai în cărţi şi referate speciale, ci chiar pe multe coloane, conştiincios redijate, în marile cotidiane şi reviste din Apus. O carte colectivă ca aceea scoasă de marele arheolog german Gerhardt Rodenwaldt, Neue Deutsche Ausgrabungen, 1930, vorbeşte despre noile descoperiri germane, atât din Germania (pentru toate epocile timpurilor vechi) cât şi din afară: Grecia, Asia Mică, Palestina, Mesopotamia şi Egipt, şi e de admirat într-adevăr cu ce sforţăi formidabile se sileşte arheologia germană să-şi păstreze, chiar prin vremurile prin care trece politic ţara respectivă, locul ce şi l-a cucerit în ştiinţa generală. Un cotidian ca The Times ţine la zi informaţia descoperirilor arheologice de oriunde se fac, cu aceeaşi amănunţime şi interes pe care din nefericire atâtea cotidiene de la noi şi de aiurea înţeleg să-l acorde crimelor pasionale şi atâtor alte fapte păcătoase omeneşti.

Revenind însă la noi şi iertat fiindu-mi de a vorbi într-o cauză care numai aparent este a mea, de îndeletniciri şi răspundere profesională, este a unei întregi generaţii de cercetători care se silesc fiecare să lumineze o problemă sau alta dintre atâtea ce stau acoperite de taină la începutul istoriei noastre naţionale, - vă voi înfăţişa în cele ce urmează, în strict rezumat, tot ce e mai de seamă ca noi descoperiri arheologice din ţara noastră, în noul volum al „Daciei” apărut acum, apărut vă asigur cu destule greutăţi, ca să merite puţină atenţie şi recunoaştere.

Oricum s-ar caracteriza faza de acum a istoriografiei noastre, în slujba căreia arheologia îşi are rolul ei bine definit, un lucru este sigur şi mai presus de orice îndoială: avem şi vom avea întotdeauna nevoie de trecut, deci de oglinda acestuia care este istoria. Înlături deci, cu neîncrederea sau scepticismul cu care pare că e o modă a se considera ici-acolo, aiurea şi la noi, cercetările istorice şi istoria însăşi. Mai mult decât atât. Cred că nu greşesc când văd astăzi că sensul şi viitorul acestor cercetări şi la noi se îndreaptă, pe de o parte în lărgirea cadrului geografic de informaţii referitoare la întreg trecutul nostru, deci tot alte şi iarăşi alte izvoare neîntrebuinţate din ţările vecine până astăzi în Turcia, pe de altă parte, printr-o egală extindere a cadrului nostru de cercetare în timp, până în paleolitic. Începutul istoriei generale şi a noastre cu crearea lumii şi Vechiul Testament ne apare astăzi tot aşa de nefiresc şi de naiv nevinovat ca acela cu Roma lui Romulus şi Remus, Rea Silvia şi regalitatea legendară romană. Chiar antiteza de duioasă amintire şcolărească - Decebal şi Traian - aparţine evident altei vremi şi se poate întrebuinţa încă numai spre simplificare şi intuiţie istorică în învăţământul elementar. Problema descălecatului întâi cum sugestiv i-au zis cronicarii Renaşterii noastre din al XVII-lea veac are astăzi un cadru incomparabil mai larg, în cuprinsul căruia trebuie să se facă neîncetate cercetări de adâncire şi precizare. Când acum aproape 100 de ani - în 1839 - un organizator al învăţământului obştesc ca Petrache Poenaru, publica în numele Eforiei Şcoalelor, hotărârea că ,acum - zicea el - când se află un depozitoriu (depozit) de obiecte în Colegiul din Bucureşti cu perspectiva de a se transforma în „Museu National” nimeni nu mai are voie a-şi însuşi vreun obiect de antichitate şi îndată să-l trimeată prin ocărmuire la Depositoriul din Colegiul Sfântul Sava”, şi tot el zicea „nimeni să nu fie voinic a scormoni în pământ pentru a scoate obiecta de antichitate". (Buletinul Oficial din 3 Noiembrie 1839, Cf. Ştefan Pop, Colegiul Sf. Sava, Boabe de Grâu_IV, 1933, p.414-415), - un mare pas mai departe se făcea în direcţia descoperirii şi conservării monumentelor istorice, oricât de imperfectă până în ziua de astăzi, mă gândesc mai ales la lipsa unui local propriu şi înzestrat cum trebuie a acelui „Museu National” pe care-l vedea aşa de bine încă Petrache Poenaru şi generaţia sa de cărturari şi de patrioţi.

Pe această linie, cu multe şi mari greutăţi, s-a mers totuşi mai departe. De la 1864 avem un Muzeu Naţional care încetul cu încetul a adunat multe şi mari bogăţii. De la 1864, 1873 şi 1874, 1913 şi 1919, 1932, avem legi şi regulamente care, în parte se aplică - ca pretutindeni şi întotdeauna aplicarea legilor atârnă de oameni. De la Vasile Pârvan a rămas şi un proiect de lege pentru înfiinţarea unui Institut Arheologic al României, asemenea cu acela pe care îl au toţi vecinii şi toate ţările apusene.

Iată mi se pare locul în care se cuvine a vorbi despre noile descoperiri cuprinse în cel mai nou volum din „Dacia” 
întemeiată de Vasile Pârvan, „organ al unui Institut Arheologic care nu există” zicea el cu amărăciune, - organ al unui Institut Arheologic care va trebui să existe, zice împreună cu mine întreaga generaţie a cercetătorilor de astăzi pe acest tărâm, chiar dacă celor mai în vârstă din mişcarea noastră ştiinţifică nu le va fi dat să-1 vadă. Instituţiile care sunt temeliile dintotdeauna ale Statelor, puterea şi prestigiul lor de legitimitate, sunt mai presus de oameni, mai presus chiar de generaţii întregi.

Istoria noastră naţională începe astăzi cu paleoliticul, nu fiindcă trebuie sau fiindcă aşa se face şi aiurea, ci fiindcă în chip firesc la aceleaşi concluzii conduc cercetările şi descoperirile astăzi şi la noi, iar acestea toate dovedesc în deplinul înţeles al cuvântului începuturile dintâi ale tuturor sforţărilor care s-au produs pe acest pământ pentru prefacerea vieţii dintr-una adânc primitivă într-una din ce în ce mai luminată, alături cu toate celelalte popoare şi ţări ale lumii.

$\mathrm{Cu}$ multe zeci şi zeci de mii de ani, o asemenea viaţă a fost, vorbesc de ce s-a dovedit până acum, în Ardeal, în Nordul Basarabiei, în Dobrogea, pe Valea Prutului şi desigur şi aiurea. Numele cercetătorilor: Dr. Martin Roşca de la Cluj, Dr. Ceslav Ambrojevici de la Cernăuţi, fraţii I. şi Dr. N. Moroşan de la Chişinău, C. Nicolaescu-Plopşor de la Craiova, paralel şi ulterior cu apariţia revistei „Dacia”, Prof. Ioan G. Botez de la Iaşi. Marele geolog, Prof. I. Simionescu a postulat demult existenţa acestei epoci şi la noi, cercetată în parte dar cu deplin succes de elevi ai săi. Marele specialist francez Abatele Breuil, într-o vizită a sa de studii la noi, după război, a adus confirmări şi o încadrare preţioasă. Se poate cita chiar un obiect documentar de o excepţională frumuseţe, ca o operă de artă pentru mult îndepărtatele timpuri, deşi ca publicare e ulterioară apariţiei revistei „Dacia”: e un splendid vârf de foaie de laur din perioada solutreiană a paleoliticului, găsit în comuna Cuconeşti, jud. Bălţi şi publicat de Dl. N. Moroşanu, în cel mai nou număr al revistei „Vasile Adamachi” de la Iaşi; originalul se găseşte la Muzeul de Antichităţi din Bucureşti.

Începând cu aşa-zisa epocă neolitică, care ţine până la 2000 î. Hr., întreaga ţară e locuită, ba chiar des locuită, ori pe unde au fost locuri potrivite de vieţuire, vieţuire pe alocuri întreruptă în răstimpuri, dar iarăşi în alte locuri continuă, sute şi sute de ani. Arheologia naţională a ajuns astăzi şi la noi, deşi suntem relativ încă la început, a preciza chiar, care au fost diversele etape succesive ale culturii ce s-a dezvoltat în diferitele noastre regiuni. În cutare loc viaţa a început de timpuriu, în altul, viaţa e ceva mai nouă, ştim ce a fost mai vechi şi ce a urmat, o cronologie adică, lucru foarte preţios pentru linia de desfăşurare a vieţii istorice, chiar lipsite fiind încă de izvoare scrise. Iar lucrurile, materialele, nu sunt aidoma, vă rog, cum li se par sau cum sunt ademeniţi să creadă uneori, chiar cu toată sinceritatea, unii istorici. Variază de la o etapă a sforţărilor la alta, de la o etapă a culturii la alta. În unele locuri mersul înainte a fost mai repede şi mai sprinten, după regiuni şi după oameni, în alte părţi a fost mai încet sau mai conservator şi vom şti odată din ce în ce mai complet, cum a evoluat Dacia noastră cu toate regiunile ei, în lupta mai departe, către bunuri şi o civilizaţie din ce în ce mai înaintată.

În întreg acest cuprins de fapte şi idei, aduc preţioase lămuriri Prof. Vasile Ciurea cu identificarea unor localităţi din jud. Baia, D-na şi Dl. Vladimir Dumitrescu prin publicarea rezultatelor din două staţiuni cu ceramică pictată din Moldova, ilustrate şi cu planşe în culori, cât se poate de reuşite. Aici un cuvânt de laudă pentru toate sforţările şi concursul tehnic al marelui Institut „Imprimeria Naţională”. Despre această civilizaţie cu ceramică pictată, reprezentată prin materialele minuţios studiate cu tot angrenajul necesar, atât se poate spune în acest scurt rezumat, reprezintă unul dintre tipurile de civilizaţie - cum se zice - ale Europei Sud-Estice, a cărei extensiune, influenţă, origine stau în strânsă legătură cu însăşi marea problemă a naşterii poporului grec din Antichitate, ce rămâne de dezlegat în viitor şi numai pe această cale a descoperirilor şi cercetărilor arheologice. Părerea nu este numai a mea, dar din această pricină, unele cercuri ştiinţifice apusene aşteaptă de la noi cu mult mai mare interes materiale arheologice din al treilea şi al doilea mileniu î. Hr. decât materialele referitoare la epoca romană. E un punct de vedere care fireşte nu poate fi şi al nostru. Romanitatea noastră, privită din punct de vedere arheologic, reprezintă un mare capitol, despre care va fi vorba îndată.

Materialele arheologice ale vieţii anterioare epocii romane sunt însă cantitativ evident covârşitoare şi în toate regiunile ţării. Exemple sunt: descoperirile şi cercetările D-lui Vasile Christescu despre staţiunile preistorice de la Vădastra, alt tip de civilizaţie străveche, din Oltenia, extrem de interesant, descoperirile şi cercetările de la Glina de lângă Bucureşti ale D-lui I. Nestor, cu preţioase preciziuni stratigrafice şi de cronologie, în sfârşit descoperirile şi cercetările D-nei şi D-lui Radu Vulpe de la Poiana din jud. Tutova, impozanta aşezare de îndelungă vieţuire - din eneolitic până în vremea romană - pe malul stâng al Siretului. Materialele bogate de la Poiana umplu aproape o întreagă sală a Muzeului Naţional de Antichităţi secţia veche casa Macca. Iar multe alte materiale care nu exclud surprize sunt încă în pământ şi vor fi dezgropate pe rând.

Două depozite de bronzuri - dacă obiectele ar fi de aur li s-ar zice comori, precum şi un mormânt celtic, toate trei din Transilvania, publicate de Dl. Martin Roşca reprezintă industria metalelor la noi în al doilea şi întâiul mileniu de eră creştină. Depozitele arheologice indică drumurile de producţie şi de comerţ, centre de difuziune şi arii de 
răspândire. Mormintele cu caractere distincte etnice sunt tot aşa de preţioase, mai ales când sunt mai multe în aceeaşi regiune, pentru a dovedi infiltraţia şi prezenţa de neamuri succesive care pe rând au ocupat acele regiuni în mijlocul populaţiilor autohtone. Prezenţa la noi a Celţilor şi caracterul acestei infiltraţiuni, pe singura această cale a descoperirilor arheologice va putea fi elucidată şi mai bine în viitor.

Cu mileniul întâi î. Hr., noi vremuri se deschid pentru istoria noastră, până şi după cucerirea romană. Vasile Pârvan le-a zis în chip foarte potrivit epoca de penetraţie elenică şi elenistică şi de helenism în luptă cu romanismul. Şi tot el le-a trasat marile linii de eşalonare. Dar să nu ne înşelăm. Ştim încă foarte puţin din ceea ce vom şti în viitor, numai pe calea descoperirilor arheologice: cetăţi şi colonii greceşti, drumuri, castre, lagăre şi aşezări romane, inscripţii şi monede.

În frunte stă Histria regretatului Pârvan, cercetată acum de Dl. Lambrino şi pentru ceramica greacă de D-na Lambrino. E o mină de informaţii arheologice şi istorice de tot felul, de cercetat multe decenii de acum înainte. Un muzeu local îngăduie o privire repede de ansamblu şi o vizită de neuitat a vastei aşezări. În revista „Dacia”, D-na Lambrino publică o splendidă serie rodo-ioniană din ceramica greacă de la Histria, iar D1. Lambrino continuă expunerea sistematică a materialelor de la Histria, întreruptă prin moartea profesorului său.

Pandantul ardelean şi roman e Sarmizegetusa, unde un muzeu local tot aşa de bine întocmit se datorează D-lui C. Daicovici de la Universitatea şi Institutul de Studii Clasice din Cluj. Aedes Augustalium şi Forul de la Ulpia Traiana constituie una dintre descoperirile capitale mai noi pentru viaţa romană a Daciei, despre care ar fi să se vorbească special şi aici, de chiar autorul ei. Fără nicio exagerare, pot afirma că arheologia românească a descoperit în Ardeal numai în câţiva ani cu mult mai mult pentru viaţa romană şi băştinaşă a Daciei decât regimul trecut în întreg ultimul veac de activitate arheologică care poate conta. Şi e firesc să fie aşa, pentru că pe noi lucrurile acestea ne dor şi trebuie să ne stea neîncetat la inimă.

La Callatis (Mangalia) ca şi la Tyras (Cetatea Albă) unde au lucrat şi lucrează D1. Sauciuc Săveanu şi D1. Paul Nicorescu, condiţiile de lucru sunt deosebit de grele faţă de situaţia actuală a locurilor unde nu se poate săpa liber. Şi totuşi s-au găsit materiale preţioase, în completare şi cu unele noutăţi de informaţie deosebit de remarcabile prin interpretările şi locul ce li se vor fixa. Surprize nici aici nu sunt excluse şi se va stărui.

La Capidava (Callachioi), regiunea Cernavodă, unde a lucrat şi lucrează D1. Grigore Florescu, tot aşa, în plus se face consolidare pentru păstrarea însemnatelor ruine.

D1. Cantacuzino publică o serie întreagă de ştampile de pe mănuşi de amfore găsite în România şi greutăţi din Dbrogea. Relaţiuni comerciale între lumea daco-getică şi îndepărtate [...] se precizează prin aceste materiale.

D1. Vasile Christescu, acelaşi săpător de la Vădastra (Oltenia), publică şi câteva monumente romane de la Apulum (Alba Iulia).

În chip simbolic, ne-am bucurat că s-a potrivit aşa, bătrânul numismat Mihail Şuţu, cu puţin înainte de a se stinge, a ţinut mult să-şi publice în „Dacia” o comunicare a sa la Academie, să o vadă în extras şi să o predea la Înalt loc, comunicare unde pune din nou problema tezaurului nostru de la Pietroasa, pentru a cărui cercetare a instituit şi un premiu la aceeaşi instituţie. Mihail Şuţu a debutat ca arheolog în Revista pentru Istorie, arheologie şi filologie a lui Grigore G. Tocilescu, publicând în anul I vol. I, 1885 - Tezaurul de la Turnu Măgurele, astăzi la Moscova. Revista „Dacia” întemeiată de Vasile Pârvan şi reapărută acum cu toţi colaboratorii şi-a făcut o datorie şi s-a cinstit pe sine legând vechile fire după aproape 5 decenii cu mănunchiul de sforţări ale lucrului nostru arheologic din vremea de faţă.

Un singur cuvânt de adaos. Cele mai multe din descoperirile de mai sus s-au făcut până în 1927-1928. Altele în continuare au urmat în toţi anii, în toate părţile ţării şi pentru toate epocile mai sus trecute în scurtă privire, cu rezultate dintre care unele sunt fără nicio exagerare de o însemnătate excepţională, şi se studiază şi vor face obiectul altor expuneri şi dări de seamă speciale.

\section{Artele în timpurile preistorice la noi (I)}

Nu puţini, poate chiar mulţi dintre cinstiţii ascultători de astă seară se vor fi întrebat: avut-am şi noi artă sau arte, în timpuri aşa de vechi? Deci, înainte de legăturile cu lumea mai fericită a Apusului şi cu Bizanţul? Înainte de întemeierea Principatelor, ba chiar înainte de Creştinism şi de Romani, ca şi de Coloniile greceşti de la Marea Neagră, care, cu mult înainte de era Creştină, au adus în părţile noastre multe din frumuseţile civilizaţiei sudice, greceşti şi mediteraneene? 
Răspunsul a fost dat demult. L-a dat cel dintâi, în chip amplu şi sigur, după toate cunoştinţele vremii sale, maestru, evocator şi plin de sugestii: Alexandru Odobescu de la naşterea căruia anul acesta s-au împlinit o sută de ani. E memorabilă conferinţa rostită la Ateneul Român acum 62 de ani, la 17 Decembrie 1872, cu titlul „Consideraţiuni generale asupra artei în ţară la noi. Artele în perioada preistorică”.

Ce spunea Odobescu? Sprijinindu-se pe noţiunea de bază a vechilor filozofi şi artişti eleni - frumosul şi binele, adoptată de toate naţiunile de seamă ale lumii, el îndemna cu pasiune pe iubitorii de frumos ai vremii sale: „Studiaţi rămăşitele, oricât de mărunte, ale producţiunii artistice din trecut...spicuiţi cu o pietoasă îngrijire rămăşitele artei străbune" pe care el se mărginea în rolul de a le urmări şi înfăţişa ca rezultat al cercetărilor sale.Rezumând starea din trecut a ţării noastre şi deplângând vicisitudinile care au împiedicat în aşa de lungi răstimpuri să facem ceva mai de seamă şi să fim mai bine cunoscuţi în lume, Odobescu reuşeşte a fixa în acest trecut etapele, perioadele, prin care, împotriva tuturor adversităţilor, viaţa noastră trecută şi-a urmat cursul:

1. „Periodul preistoric şi nu numai dacic, care în nemărginita sa întindere, a trebuit să prezinte faze multe şi felurite şi stări, zicea el încă cufundat într-un adânc întuneric".

2. „Al doilea period este periodul roman care se deschide cu al doilea secol al erei creştine”.

3. „Al treilea period ne dă iarăşi înapoi pe calea civilizaţiunii şi ne cufundă într-o adâncă învălmăşeală; îl numim periodul barbar, şi făcându-1 să înceapă deodată cu ivirea Goților în Dacia, la 274 după Hristos, el ne înfăţişează, în curs de aproape 1000 de ani, o clătire neîncetată de neamuri inculte, îmbrâncindu-se pe acest nenorocit pământ ce-1 disputau pe toată ziua coloniilor romane care se împământeniseră aici. Puţinele spuse ce găsim în istorie despre feluriţii Barbari, nu ne sunt de ajuns spre a putea statornici caracterele tuturor rămăşiţelor clasice ce au putut lăsa, pe solul nostru, popoare precum erau Vizigoţii, Hunii, Gepizii, Avarii, Bulgarii, Slavonii, Ungurii, Pacinaţii, Iazigii, Cumanii şi câţi alţii”.

4. ,În fine de la întemeierea Statelor Române încoace, adică de la sfârşitul secolului al XII-lea, noi începem a socoti un al patrulea period pe care-l putem numi curat românesc, şi ale cărui monumente, cu atât mai rare cu cât sunt mai vechi, au un caracter foarte bine lămurit".

Cu o admirabilă intuiţie care nu odată l-a făcut să vadă departe şi să vadă bine, Alexandru Odobescu deosebeşte cu claritate pe de o parte, care sunt timpurile total lipsite de monumente şi izvoare scrise, pe de alta, acelea în care, deşi la început cu izvoare scrise puţine, încep vremurile istorice. Mult mai târziu, în vremea noastră (1911), un mare istoric şi arheolog francez Camille Jullien avea să spună în felul său tot aşa despre aceleaşi vremuri de trecere: „Nous marcheons dans cette heure incertaine qui n'est pas encore le jour, qui n'est deja plus la nuit” - e ora nesigură, când nu e încă ziuă dar nu mai e noapte. Idées communes et faits généraux à la fin des temps prehistoriques, lecţie la Collège de France din 6 Decembrie 1911 în Au seuil de notre histoire, 1930, p. 141.

De altfel nouă, surprinzătoare la Odobescu e şi cealaltă concepţie a sa, privitoare la Evul Mediu barbar, care, tot aşa de lipsit de izvoare scrise ca şi timpurile de sfârşit ale preistoriei, numite convenţional protoistorice, face parte integrantă prin toate rămăşiţele arheologice ce a putut lăsa istoria, din domeniul de preocupare şi cercetări ale arheologiei preistorice şi preistoriei. Aşa se lucrează astăzi în toate părţile.

Odată făcută însă această delimitare şi împărtăşire, o întrebare se ridică, în chipul cel mai firesc, fiindcă este absolut logică. Fost-a într-adevăr artă, fost-au cu adevărat arte acelea ce au apărut şi la noi, în aşa de îndepărtatele timpuri, preromane, precreştine şi chiar preelenistice? Ce fel de arte vor fi fost şi cum se explică?

$\mathrm{Cu}$ o nouă surprindere care se ridică până la admiraţie pentru puterea de discernământ a liniei drepte într-o complicată chestiune de arheologie şi estetică, înainte de progresele realizate de aceste discipline în vremea noastră, constatăm ca şi de astă dată, Alexandru Odobescu a văzut bine şi a văzut drept.

„Fiecare popor, din câte au venit pe rând aici, şi-a adus cu sine mult puţina sa cultură. Dar oare toate avut-au ele o cultură artistică? Lăsat-au ele urme de producţiuni artistice?"'

„Cei mai mulţi ar răspunde îndată: Nu!”

„Eu însă nu cutez a mă hotărî aşa lesne, într-acest caz, pentru negativ”. „Daţi-mi voie să mă explic”.

Iar explicările sale, pe care nu le voi transcrie în întregime, se văd exemplele pe care le dă şi care cu deosebire ne interesează aici:

„Limbile moderne n-au găsit un termen generic special spre a denumi toate acele întrupări omeneşti, toate acele superfetaţiuni plastice, care nu sunt după gustul nostru modern. Arheologii se văd astăzi siliţi a le chema şi pe 
dânsele obiecte de artă; şi eu fac bine, căci şi acelea purced din acelaşi instinct al spiritului omenesc. Dolmenele şi menhirele, acei colosali bolovani de piatră grămădiţi de Celţi în codrii Armoricei (Odobescu nu putea şti, fireşte, că şi la noi aveau să se găsească menhire), au aceeaşi sorginte psihologică cu Partenonul lui Ictinus şi al lui Fidias; ciolanele de animale zgâriate, în timpii preistorici, cu figuri de urşi şi de cerbi, ce s-au găsit îngropate sub structuri adânci în cavernele Dordoniei sunt şi ele fraţi de cruce cu Apolonul din Belvedere şi cu Moise al lui Michellangello".

„Ce să mai zic? Sălbaticul din insulele Viti ce-şi mâzgăleşte şi-şi tatuează corpul cu colori pestriţe, o face şi el dintr-un cuget analog cu acela care 1-a îndemnat pe Rafael să zugrăvească nemuritoarea sa frescă a Şcolii din Atena".

„În toate aceste lucrări, grosolane sau sublime, aceeaşi intenţie, acelaşi spirit domneşte: dorinţa de a face un ceva care să dea o înaltă idee despre măiestria omenească”.

„Însă fiecare epocă, fiecare popor chiar, se pricepe într-altfel a pune în lucrare acea nobilă dorinţă. De acolo provin gândurile în perfecţiunea artelor; de acolo provin ceea ce numim stilurile”.

„Este un fapt netăgăduit că fiecare seminţie omenească - am putea zice fiecare ramură a seminţiilor, fiecare popor distinct, are în geniul său un mod special de a concepe şi de a produce frumosul plastic".

„Acea originalitate a simţului estetic se vădeşte în producţiunile unui popor, de la unealta casnică până la cel mai monumental edificiu".

Ceea ce spunea Alexandru Odobescu la 1878, o spune Camille Jullien de la 1907 încoace, cu unele exemplificări surprinzător asemănătoare. Ascultaţi numai:

„Orice monument, oricare ar fi, oricât de mic ar fi, tot ceea ce omul a pregătit cu mintea sa şi a lucrat cu mâinile sale trebuie să-şi afle locul într-un capitol al istoriei noastre naţionale. Din epoca în care apare pe o bucată de cremene semnul acestei minţi şi acestei mâini, istoricul are datoria de a interveni. Săgeata, dolmenul şi peştera pictată îi aparţineau acelaşi titlu ca Acropolea, Notre-Dame de Paris şi La Maison Carrée”.

„Să nu se zică că depreciem, apropiind aceste două grupe de lucruri. Săgeata şi dolmenul au frumusețea lor şi măreţia lor, şi pot fi mărturie despre tot aşa de puternice sforţări de muncă şi de ideal, ca şi capodoperele lui Fidias: zic sforţări şi nu rezultate. Iată, de exemplu, vârfurile de silex găsite la Volgu în Saône-et-Loire şi păstrate aproape toate în Muzeul din Chalon-sur- Saône; forma lor zveltă, prelungă şi regulată aminteşte foile de laur, unul dintre arborii noştri cei mai decorativi; ele sunt aşa subţiri că le-am zice transparente; marginile nu prezintă niciun unghi în afară, nicio ruptură dizgraţioasă şi ele se termină într-o curbă armonioasă pe care n-ar dezavua-o un cizelor alexandrin. Epoca pietrei cioplite a cunoscut visări şi pasiuni de artişti tot aşa de bine ca şi epoca marmurei lustruite din timpul lui Temistocle şi al lui Pericle. Şi închipuiţi-vă, că pentru a ajunge la asemenea rezultate, pe o lamă de cremene lungă de $35 \mathrm{~cm}$, lată de $10 \mathrm{~cm}$, groasă abia de câţiva mm, a trebuit să se facă să sară sute de ţăndări, dând sute de retuşuri şi întotdeauna cu mâna, într-un gest de precizie şi uşurinţă infinite. Astfel, din timpurile pietrei şi ale peşterilor, această mână a omului, principala cauză a progreselor lui şi prim auxiliar al inteligenţei sale, mâna aceasta era bună pentru operele de cea mai lungă durată, cele mai răbdătoare, cele mai delicate şi se supunea cu o incomparabilă docilitate voinţei care o conducea. Brutală în zilele de luptă, aceeaşi mână avea în ceasurile de lucru, o minunată dulceaţă. Iată ce ne învaţă silexurile de la Volgu sau de la Solutré: spuneţi-mi, vă rog, dacă ele nu manifestă ceva istoric tot aşa de bine ca şi palatul din Versailles, cântecul lui Rolland şi bătălia de la Waterloo. Aceste pietre, aceste silexuri a spus odată Fustel de Coulanges ,tout acela, c'est de l'histoire, et c'est aussi un âge de l'humanité". Op.cit.I. 58-60.

Avea deci dreptate Alexandru Odobescu, care era chiar cu mult mai rezervat. Şi avea de ce fi. Cercetările erau cu totul la început. El le întrevede însă, le postulează şi le cere. Iar dovezile n-au întârziat prea mult să vină. Nu e staţiune preistorică astăzi care, dintr-o anumită fază şi până la anumite limite în timp, ce se cunosc (căci avem şi o cronologie la care lucrează cu contribuţiile lor valoroase toţi arheologii noştri), lucrul silexului, până la cel mai minuţios, de reală frumuseţe artistică potrivită cu vremea să nu fie reprezentat, adeseori exemple ce vor trece în manuale: lame, vârfuri de săgeţi şi lance, etc, mărturii ale lucrului propriu, care fac să se deosebească o staţiune de alta şi în unele locuri chiar ateliere. Ele fac parte din munca cea mai aleasă a celor mai vechi locuitori ai ţării noastre şi vom vedea că nu e singura: măiestria şi sufletul lor se manifestă şi altfel.

Citam şi altă dată şi merită citată ori de câte ori, ca să fie văzută şi apreciată, splendida foaie de laur solutreană găsită anii din urmă la locul „În Ponoară”, comuna Cuconeşti, judeţul Bălţi, pe malul stâng al Prutului, de profesorul Nicolae Moroşanu de la Chişinău. Descrierea corespunde am zice aidoma cu aceea citată a silexurilor de la Volgu, admirate de Camille Jullien. Preţiosul obiect se găseşte la Muzeul de Antichităţi şi e o lucrare de adevărată artă în 
deplină potrivire cu toate cele spuse sau citate mai sus. Şi câte altele se vor fi găsind pe pământul nostru! De aici necesitatea imperioasă a cercetărilor şi săpăturilor, faţă de a căror însemnătate, mai ales când avem cu cine le face, fie-mi îngăduit să aduc o sugestie de aiurea.

Vorbind despre Asia Mică, marele om de stat care a fost Clemenceau şi care nu era nici arheolog şi nici istoric, despre Asia Mică cu atâtea monumente istorice şi preistorice, Clemenceau a zis odată după război: „Nu s-a săpat acolo nici a suta parte. Ceea ce este adânc întristător este să vezi că Şcoala Franceză de Atena are în totul şi pentru toate, ca să-şi facă săpăturile sale, un credit de câteva mii de franci, pe când Englezii, Germanii, Americanii sosesc cu milioane, deschid şantiere, etc".

În proporţiile cuvenite, sperând şi noi în asemenea vremuri care vor trebui să vie, dar revenind la firul expunerii noastre în partea ei ultimă de astăzi, un lucru rămâne cred sigur: marea vechime a artei şi artelor, pretutindeni şi la noi; în al doilea rând, caracterul ei ca atare, bine determinat, încă de la începutul manifestărilor ei şi pe care-1 atestă şi arheologia şi teoria filozofică a artei cum se concepe astăzi.

Ce spune arheologia? Arheologia descoperă şi ilustrează, dă materiale de interpretare şi discuţie, pe regiuni şi ţări, din toate continentele. Vechiul repertoriu asupra artei paleolitice al lui Salomon Reinach ar putea lua astăzi proporţiile unui adevărat Corpus ce va fi întocmit, desigur, într-un timp nu prea îndepărtat. Lucrarea relativ recentă (1929) a lui Herbert Kühn, Kunst und Kultur der Vorzeit Europas: Das Paleolitikum are nu mai puţin de 120 de planşe, în afară de mai multe planşe colorate, figuri în text şi hărţi. În 1928, a apărut primul volum din marea publicaţie colectivă, dirijată de Dr. H. Bossert, Geschichte des Kunstgewerbes, care începe cu arta industrială a paleoliticului, datorită aceluiaşi Herbert Kühn care, pe de altă parte, scoate de la 1925 marea revistă de caracter internaţional JPEK (Jahrbuch für prähistorische und etnographische Kunst), ajunsă la al optulea volum, în ultimul şi cu o însemnată contribuţie românească despre plastica antropomorfă a regiunilor noastre la sfârşitul Neoliticului, asupra căreia vom reveni la locul potrivit.

Repet, Alexandru Odobescu a văzut bine şi a văzut departe. Materialele noastre se înmulţesc cu fiecare săpătură, în fiecare an, ilustrând tot alte laturi ale vieţii noastre străvechi şi arta de atunci, din toate perioadele, precizându-se tot mai bine cronologia lor şi stilurile diverse ce s-au succedat.

Pe de altă parte, cele mai noi teorii ale artei nu numai că nu contrazic părerile arheologilor şi istoricilor, ci le întăresc. Cineva povesteşte că Rodin în neuitatele sale conversaţii repeta continuu că ,arta n-are dimensiune. O medalie poate să fie tot aşa de mare ca şi timpanul bisericii de la Madeleine. E destul ca sculptorul să ştie să o însufleţească”. Transpuneţi aceste consideraţii pentru îndepărtatele timpuri străvechi.

Iar Romain Rolland spune undeva: „O artă poate să decadă, dar arta nu moare niciodată. Este foarte clar, că la un popor ruinat, sfâşiat de războaie sau de revoluții, forţa creatoare va putea cu anevoie să se exprime în arhitectură: arhitectura cere bani, ea reclamă construcţiuni noi, bunăstare, încredere în viitor. Artele plastice în genere au nevoie pentru ca să înflorească, de lux şi plăcerile unei clase rafinate, un oarecare echilibru de civilizaţie. Dar când condiţiile materiale ajung mai apăsătoare, când viaţa devine aspră, săracă, hărţuită de griji, când îi este interzis să se dezvolte în afară, ea se întoarce asupra ei însăşi şi eterna ei nevoie de fericire o face să găsească alte drumuri artistice; frumusețea se transformă; ea devine interioară, ea se refugiază în artele profunde: poezia, muzica. Ea nu moare. Nu există nici moarte nici renaşterea umanităţii. Lumina nu încetează niciodată să ardă; ea se deplasează numai, merge de la o artă la alta şi de la un popor la altul. Dacă nu veţi studia decât una din ele, veţi găsi în istorie întreruperi, sincope, când inima încetează de a bate. Pe când, dacă veţi contempla ansamblul tuturor artelor, veţi simţi cum curge eternitatea vieţii”.

Transpuneţi vă rog şi aceste consideraţiuni adânc simţite şi adevărate în îndepărtatul trecut de începuturi şi trecerea umanităţii de la preistorie la vremurile istorice. Între „natură, tehnică şi artă” cum clar şi convingător face apropierile şi deosebirile între ele, un cunoscut estetician al nostru, avem elementele de bază pentru prezentarea mai departe, după puterile noastre, 62 de ani de la Alexandru Odobescu, a artelor din timpurile preistorice la noi.

\section{Artele în timpurile preistorice la noi (II)}

Am văzut altădată că şi la noi artele sunt foarte vechi. Alexandru Odobescu e cel dintâi care a stabilit cele mai vechi etape ale artelor la noi şi împărţirea sa este bună până în ziua de astăzi şi o vom întrebuinţa. E, am zice, o împărţire clasică, ca şi aceea cu care se lucrează în istoria generală şi dacă în istoria generală această împărţire este satisfăcătoare şi se menţine, cu toate discuţiile ce s-au ivit şi se pot ivi în delimitarea mai precisă a epocilor şi perioadelor, discuţie în care însă niciodată nu trebuie să se uite că timpul nu stă în loc şi nici viaţa nu încetează 
cum încetează viaţa fiecăruia dintre noi, - cu atât mai puţin zic e zadarnic a introduce în artele străvechi, sau în arheologie, împărţiri noi sau cine ştie ce puncte de vedere complicate, altele decât ale celor ce ne-au precedat, iar aceasta cumva de hatârul originalităţii uşoare a popularităţii repezi. Să o facă alţii şi aiurea, decât în ştiinţa trecutului şi a artelor.

Am văzut de asemenea, tot atunci, că artele ce au existat şi pe care le-am avut şi noi în cele mai vechi timpuri, trebuie considerate ca arte, ca artă, în toată puterea cuvântului. Spusele adânc cugetate şi bine cernute ale lui Alexandru Odobescu le-am întărit cu părerile altor reprezentanţi mai noi din acelaşi domeniu, constatând chiar asemănări surprinzătoare, pentru noi foarte explicabile, dovadă că aşa stă adevărul. Nu se poate zice: monumente foarte însemnate şi monumente foarte puţin însemnate. Iată nişte cioburi, nişte fiare vechi. - A! se schimbă socoteala, când e vorba de aur sau de argint. Numai că nu este aşa. Altfel decât în viaţă, şi chiar în istorie, mă gândesc la istoria politică, - în artă, materialele cele mai preţioase sunt numai pus şi simplu: materiale; totul e: ceea ce a făcut omul dintr-însele, monumentele, de la cele mai mărunte şi până la statuia zeiţei Atena Parthenos. Un istoric, un cartist chiar, omul textelor, al cărţii şi al izvorului scris, povestind recent viaţa marelui istoric şi om politic din Franţa veacului trecut, Thiers, spune despre dânsul, când, din mijlocul luptelor politice, se întorcea în opoziţie: „le voici homme de lettres et philosophe dans l'âme; il se donne le spectacle des choses humaines par les monuments et les livres, c’est-à-dire par tout ce qui reste des hommes d’autrefois” (Malo, Thiers, Payot 1932, p.272). Monumentele şi cărţile, izvoarele scrise, sunt singurele categorisiri posibile între mijloacele de cunoaştere ale trecutului, de la cel mai apropiat până la cel mai îndepărtat.

Am mai văzut, în sfârşit, rândul trecut, ceea ce marele Odobescu nu putea să ştie pe vremea sa, dar a prevăzut, că străvechimea artei şi artelor, pretutindeni şi la noi, şi tot aşa caracterul lor ca atare, bine determinat încă de la începutul manifestărilor lor, sunt atestate astăzi deopotrivă, pe de o parte de arheologie, pe de alta de teoria filozofică a artei. Momentele nu sunt puţine, din contra, chiar pentru cele mai vechi începuturi, iar caracterul lor de artă adevărată e confirmat de cele mai noi consideraţii şi teorii estetice. Lucru foarte de seamă, asupra căruia nu trebuie să trecem prea repede, pentru mai buna înţelegere a celor ce vor urma.

Căci mai ales o întrebare mi se pare că se ridică, fiind vorba despre timpuri aşa de vechi, şi despre aceasta vom vorbi astăzi. Cu ce artă avem de-a face? Această aşa socotită artă, fie paleolitică, fie neolitică, din epoca de bronz, din Hallstatt sau La Tène sau din vremea barbară, - nu e oare numai ceea ce se numeşte lucru manual sau tehnică, cel mult artă industrială, prime începuturi extrem de anevoioase din ceea ce va fi mult mai târziu maşinismul? Unde încetează tehnica şi unde începe arta?

Lăsând la o parte dolmenii care sunt elemente de arhitectură propriu-zisă, de caracter precis funerar şi religios, sua menhirii, de caracter vădit plastic (şi de plastică nu minoră, cel puţin prin dimensiuni), nu se merge prea departe când se pun alături de dolmeni, săgeţile de silex, cum face Camille Jullian şi nu numai el, sau atâtea alte lucruri foarte frumos lucrate din silex, aproximativ din aceeaşi putere de expresie, evident foarte redusă, ce are în artă un aşa de mare rol? Răspunsul la aceste întrebări ne va conduce, cred, la cea mai potrivită prezentare şi caracterizare a artelor din timpurile cele mai vechi la noi, ,,periodul” întâi cum zicea Odobescu, ,şi nu numai dacic”, perioadă pe care, fireşte, el o privea aşa de nebulos în nemărginita ei întindere, cu fazele ei multe şi felurite, zicea el, cufundată ţîntr-un adânc întuneric".

Fără a ne abate prea mult în ce priveşte latura estetică a problemei, ea se înfăţişează de cei cu specială cădere a se pronunţa asupra acestei chestiuni, camere în felul următor.

„Când priveşti, zice un estetician al nostru care ne dispensează a apela la alte autorităţi străine, aşa numitele ziduri ciclopiene de la Mycena sau Tiryns, fortificaţiile întocmite din blocuri colosale de piatră încă din epoca pelageiană, aşa cum ele odihnesc pe temelia lor de stâncă, ai impresia că munca naturii nu s-a oprit odată cu apariţia omului. Straturile geologice continuă cu cele arheologice. Acţiunii puterilor naturale şi rezultatelor lor li se adaugă operele artei”. Foarte dreaptă observaţie, care se poate exemplifica şi la noi, cu atâtea aşezări şi adăposturi paleolitice, cu multe sute şi sute de cetăţui şi alte feluri de aşezări neo şi eneolitice, sau cetăţui mai noi cu înrâuriri de caracter ciclopian (dar după felul locurilor noastre, ca la Sărata Monteoru), sau atâtea cetăţui dace, cetăţi greco-romane sau puncte de trecere barbare şi care, toate-toate, s-au topit, dar nu cu desăvârşire în cuprinsul exuberant al naturii noastre, de o bogăţie, de o varietate şi frumuseţe cum nu este alta pe lume.

Şi altă observaţie de caracter estetic care se potriveşte perfect mi se pare, cu felul în care trebuie înţelese artele în timpurile cele mai vechi, de pretutindeni şi de la noi. „Arta are ceva şi din maşină şi tehnică”. „Examinarea situaţiei pe care o ocupă în mijlocul realităţii, permite înţelegerea artei ca opera puterii plastice a naturii conţinându-se în tehnica omului. Fiind în acelaşi timp natură şi tehnică, arta reprezintă punctul unei încrucişări, domeniul unei interferenţe". Transcriem de asemenea întocmai şi demonstraţia, rămasă celebră, zice d. Tudor Vianu, a lui H. Bergson din „L 'Évolution créatrice”: , Spiritul se regăseşte în lucruri”. „Iar dacă spiritul se poate oglindi în lucruri 
fie prin caracterul lui de activitate spontană şi inconştientă, făurind genul naturii, fie prin facultatea lui de a lucra după cauze finale conştiente, făurind genul tehnicii, este legitimă aspiraţia de a-şi satisface nevoia de unitate, recunoscând între ele domeniul intermediar al artei”.

Preţioase sunt de asemenea părerile rezumate ale lui Et. Souriau, care „urmăreşte o identificare cât mai completă a artei cu o anumită formă a muncii”. „Pentru gânditorul francez arta este funcţiunea skeupoetică a sufletului, funcţiunea creatoare de lucruri. Evident, în munca omului există elemente numeroase şi variate”. „Faţă de toate aceste varietăţi ale muncii, arta este, pentru Souriau, tipul activităţii care urmăreşte producerea unui lucru determinat, a unei quidităţi reale şi singulare. Activitatea manufacturieră nu devine artă decât în aceste condiţii. În complexul unei industrii se pot distinge toate formele muncii, acţiunea artistică revenind aceluia care le concepe în conexitatea lor şi ştie să le îndrume către creaţia finală a lucrului. Orice creator de lucruri este un artist. Muncitorii care cred că pot să-şi rezerve acest titlu, arhitecţii şi artiştii plastici, compozitorii şi poeţii constituie numai o speţă dintr-o clasă generală".

Aceasta este concepţia lui Souriau, pentru transmiterea căreia îi suntem foarte recunoscători esteticianului român, cu regretul însă de a nu fi exact de aceeaşi părere, atunci când acesta socoteşte concepţia lui Souriau, cu toate meritele ei, exagerată, excesivă şi în parte inexactă.

Când zici: „Arta nu este un lucru, ci aparența unui lucru” sau ,arta aparţine regiunii ideale a aparenţelor”, mi se pare numai o parte de adevăr sau chiar numai un punct de vedere. Cu totul de acord sunt însă când autorul nostru zice: ,pe de altă parte, prin opera de artă întrevedem personalitatea artistului”, sau ,în lucrarea artistică preţuim pe lucrător, îndemânarea lui, vigoarea şi originalitatea sufletului său”. Exemplele alese, cu toată nuanţarea, nu mi se par iarăşi deplin convingătoare. Iei o bucată de stofă, o unealtă agricolă etc. şi zici: ,,astfel de obiecte comparate cu operele de artă sunt cu mult mai opace”. Desigur. Aşa este. Sau „sufletul producătorului lor nu transpare prin ele”. Fără îndoială că-i aşa, dar de când? Nu a fost întotdeauna aşa! Perfecţionarea tehnicii şi maşinismul, relativ recent, cu toate originalele vechi, ele au adus aceste stări, faţă de care bietul om a ajuns să nu mai însemne aproape nimic. Fără a ne abate iarăşi într-o chestiune şi mai de amănunt, se ştie şi timpul când s-a produs acest fenomen: e a doua jumătate a veacului trecut, fireşte, nu în acelaşi timp peste tot. Şi la noi, tot aşa. E curios, dar explicabil, că cel dintâi a simţit-o un poet, ce-i drept cel mai mare poet al nostru: „Şi când vin cu drum de fier, toate cântecele pier”. Iar fenomenul nu e unic. Pentru alte categorii de lucruri omeneşti susceptibile de creaţiuni artistice, un fenomen asemănător s-a întâmplat chiar la noi şi chiar în timpurile despre care e vorba, când în cuprinsul mileniului I înainte de Hristos, a ajuns să se întrebuinţeze în ceramică roata, dar cu aceasta s-a pus capăt unei întregi evoluții şi înfloriri splendide a ceramicii timpurilor anterioare, artă în toată puterea cuvântului. Evident, tot omul, acolo unde s-a putut, a căutat şi a găsit, apoi, alte mijloace de creaţie şi exprimare artistică, chiar în acelaşi cadru de produse: ceramica greacă care se apropie aşa de mult de arta cea mare, ceramica romană, şablonară, ceramica timpurilor şi popoarelor mai noi şi a noastră.

Revenind însă la întâmpinările aduse concepţiei Souriau, dacă credem şi noi drept foarte adevărat că: „Operele de artă, considerate ca pure organizaţii estetice, sunt rezultatele cele mai autonome ale muncii omeneşti” şi „Toate lucrările tehnice tind să câştige pentru ele un grad mai înaintat de autonomie, adică să devină mai perfecte", apropiindu-se de ,tipul autonom al artei” şi ,,arta este idealul întregii tehnici omeneşti, dar în acelaşi timp ea este produsul tehnic care a atins perfecţiunea naturii”, - punctul de vedere istoric, linia de mişcare şi evoluţie seculară şi milenară a lucrului omenesc, a civilizaţiei însăşi, ne îndeamnă a nu da factorului perfecţiune, o însemnătate exclusivă. „Un automobil este mai perfect decât un car cu boi şi mai artistic. Un ceasornic este mai perfect şi mai artistic decât o râşniţă”. Da, în afară de compararea de lucruri diferite. Pentru vremea lor însă, fiecare categorie de lucruri reprezintă ceva aparte, care te face să cauţi a vedea şi scruta felul şi sufletul oamenilor, ce rând pe rând au depus sforţări şi au realizat tot ce au putut până la un maximum, o perfecţie relativă, comparabilă cu aceea a altor timpuri, numai în măsura în care ne silim să cunoaştem alţi oameni şi alte vremuri.

Cineva 1-a întrebat pe un istoric de seamă francez, din vremea noastră, care i-au fost maeştrii preferaţi. - Am fost la Sorbonna, i-a răspuns d. Batiffol, elevul asiduu al lui Fustel de Coulanges. Cursul său era straniu de puţin populat. Eram şase studenţi care-1 urmam. Totuşi lecţiile lui care năzuiau să ne înveţe cultul textelor erau admirabile. El ne punea în gardă împotriva interpretărilor subiective, împotriva marilor construcţii filozofice, pe marginea istoriei.... „Să luăm textele” îi plăcea lui să repete. El ne învăţa să le respectăm, să le scrutăm, să vedem clar între liniile lor, să nu le diformăm îmbinându-le cu ideile noastre de astăzi. El a avut meritul de a ne convinge că trebuie să cerem oamenilor trecutului ceea ce ei gândeau, în loc de a le împrumuta propriile noastre sentimente şi propriile noastre concepţii. La şcoala sa, am învăţ̧at să iubim textele pentru ceea ce ele ne învaţă din viaţa şi sentimentele generaţiilor şi oamenilor de odinioară”. „Cea mai bună filozofie a istoriei, zice d. Batiffol şi concepţia sa e aceea a tuturor istoricilor de seamă din toate părţile, este de a arăta viaţa fiinţelor (c'est de montrer la vie des êtres)". 
Acelaşi este astăzi drumul, aceeaşi este metoda arheologiei în genere, a preistoriei şi arheologiei preistorice în special, cu deosebirea, fireşte, că în ce priveşte mijloacele, textele fiind puţine sau lipsind cu desăvârşire, ne folosim mai mult de lucruri - la vie des êtres par les choses - ceea ce se face astăzi pretutindeni şi se face şi la noi, cu sârguinţă şi iubire, pentru luminarea tot altor taine ale trecutului îndepărtat.

Iată cum credem că, după ce am netezit puţin câmpul nostru de privire, vom putea, cu mai bună înţelegere, prezenta, ceea ce-şi propunea și a şi realizat şi Alexandru Odobescu, dar acum 62 de ani, cele mai de seamă lucruri din cuprinsul artelor în timpurile preistorice la noi.

\section{Un căutător de aur: Heinrich Schliemann}

Căutători de aur au existat am zice de când lumea. Au existat desigur de când oamenii au ajuns să-şi dea seama de valoarea cu totul deosebită a acestui metal care constituie, până în ziua de astăzi, măsura bogăţiei şi puterii printre țări şi oameni.Oamenii însă, cum sunt şi au fost totdeauna, au dus preţuirea lui, din nenorocire şi de nenumărate ori, la fapte care sunt foarte departe de frumuseţea şi de nobleţea - i se şi zice doar metal nobil - acestui minunat bun, cu care Dumnezeu a înzestrat natura, ca să le fie oamenilor spre folos şi împodobire, dar la care aceştia să nu râvnească fără muncă, să nu-l dorească numai din patimă şi să nu se împodobească cu el numai din zadarnică mândrie.În diferite răstimpuri, au existat în trecut şi alt fel de căutători de aur. Întregi serii de oameni, generaţii întregi de tineri mai ales, plecând de la locurile lor până peste ţări şi mări, cu viaţa în cumpănă: după aur. Mulţi au izbutit, mulţi au pierit. Îndrăzneala pentru un scop mai înalt, cu totală uitare de sine, peste orice primejdii, este pe drept socotită ca virtute şi dintre aceia, unii au rămas în amintirea istoriei ca deschizători de drumuri noi, descoperitori, colonizatori, pionieri.

Dar mai este un fel de căutători de aur. Sunt căutătorii de comori, din toate timpurile şi până în vremea de faţă, sub ochii noştri: bieţi oameni, pe jumătate naivi, pe jumătate halucinaţi şi maniaci, ademeniţi să se gândească la bogăţie fără muncă. De aceştia avem şi noi, ba chiar dau de lucru destul de des autorităţilor, deşi de pe urma lor nu s-a ales şi nu se alege niciodată nimic, căci adevărul este unul singur. Aşa precum aurul este de preţ durabil în viaţă, numai atunci când este dobândit prin muncă şi trece prin mâini care îl merită, ajungând a ridica şi împodobi viaţa până la operele nepieritoare ale artei, tot aşa, aurul din comori - şi acesta este cazul comorilor arheologice - numai atunci are un nesfârşit preţ, când aceste comori se scot cu socoteală ştiinţifică şi pietate, din pământul de unde pot aduce la lumină minunate şi sigure lămuriri despre trecut.Este vorba: ce fel de căutător de aur a fost Heinrich Schliemann, de i s-a zis aşa, ce e drept în chip camere de personaj de roman dar şi cu mult adevăr, de către ultimul său biograf - Emil Ludwig în a sa lucrare „Schliemann - Geschichte eines Goldsuchers” (Istoria unui căutător de aur), întemeiat pe un foarte mare material inedit şi cu o prefaţă de unul dintre cei mai mari arheologi ai vremii de faţă, Sir Arthur Evans, 1932. Am zis ultimul său biograf, fiindcă cel dintâi a fost Schliemann însuşi, când era de 57 de ani, al doilea fiind arheologul german Carl Schuchhardt, care trăieşte şi astăzi şi ne cunoaşte şi pe noi destul de bine, s-a ocupat încă de mult cu valurile din Dobrogea şi în timpul războiului a săpat în Oltenia şi la Cernavodă. Schuchhardt a scris în 1890 o carte despre săpăturile lui Schliemann la Troia, Tiryns, Mykene, Orhomenos, Ithaca cu un capitol introductiv despre viaţa acestuia. E anul în care la sfârşitul lui, Schliemann moare.

Întrebarea e: ce fel de căutător de aur a fost Schliemann?Ce-i drept, o adevărată viaţă de roman a fost viaţa acestui arheolog precursor, cu care se mândresc acum Germanii până şi în cărţile de şcoală, deşi cum s-a mai întâmplat şi cu alţii din multe părţi, nu l-au preţuit îndestul pe când era în viaţă, decât aproape de sfârşit.

Vieţile de seamă aduc totdeauna vorba despre înaintaşi.

„Puţini copii se-aseamănă cu tatăl,

Ba cei mai mulţi sunt mai prejos de dânsul,

Puţini şi cei mai buni”".

Aşa sună în minunata traducere a d-lui Murnu versurile 276 şi 277 din cântul al II-lea al Odiseei, versuri pe care Emil Ludwig le pune în originalul grecesc, în fruntea celui dintâi capitol al vieţii lui Schliemann.

Schliemann i-a întrecut pe toţi ai săi, ca să ajungă unul dintre cei mai de seamă şi mai originali oameni ai vremii sale.

Născut la 6 Ianuarie 1822 în provincia Mecklemburg din Germania de Nord, Schliemann este fiul unui pastor şi din alţi ascendenţi tot pastori. Vrednic de făcut legătura, în aceeaşi provincie Mecklemburg, se născuse mult mai înainte Johann Heinrich Voss, marele traducător german al lui Homer, ba chiar Voss a trăit câţiva ani în localitatea unde s-a născut Schliemann. Voss trăia încă în anii primei copilării a fiului de pastor, de o rară vigoare vitală dar dezordonat şi totdeauna plin de datorii, al cărui fiu însă era menit să ajungă cel mai mare învietor al lumii cuprinse în epopeile legate de numele nemuritorului poet grec. 
Orfan de mamă la 9 ani, într-o familie cu 7 copii, e trimis la un unchi unde învaţă aşa de sârguincios, încât după un an, trimite de Crăciun tatălui său o compoziţie în latină, despre cele mai de seamă întâmplări ale războiului troian. Dar nu are cu ce să înveţe. Schimbă liceul cu o şcoală elementară mai practică, pe care la 14 ani o termină, dar din pricina aceleiaşi sărăcii, se vede silit să intre băiat într-o prăvălie dintr-un alt orăşel din aceiaşi provincie. De la 5 dimineaţa până la 11 seara, vinde pe bani mărunţi scrumbii, unt, rachiu de cartofi, lapte, sare, cafea, zahăr, ulei, lumânări, mătură şi face toate celelalte treburi ale prăvăliei. „Nu-mi rămânea, îşi aduce el aminte cu înduioşare la bătrâneţe, niciun pic de vreme ca să învăţ. Uitasem repede şi puţinul pe care îl învăţ̧asem în copilărie".

„N-am să uit cât voi trăi seara aceea”, scrie el în autobiografia sa, şi episodul e citat şi de Schuchhardt şi de Ludwig, „,ând a venit un morar beat în prăvălia noastră. Şi el era un fiu de predicator din Mecklemburg, dar fiindcă avusese o purtare rea, trebuise să părăsească liceul chiar înaintea examenelor, umbla haimana, bea, dar pe Homer nu-1 uitase. În seara amintită, scrie Schliemann, ne-a recitat nu mai puţin de o sută de versuri din Homer, scandându-le cu mult patos. Deşi nu înțelegeam niciun cuvânt, limba melodioasă a f/cut cea mai puternică impresie asupra mea şi cu lacrimi fierbinţi am plâns asupra tristului meu noroc. De trei ori l-am pus să repete versurile dumnezeieşti şi i-am dat pentru asta trei pahare de rachiu, plătite bucuros din puţinii bani ce erau toată averea mea. Din clipa aceea n-am încetat de a ruga pe Dumnezeu ca din harul lui să-mi dea norocul să învăţ şi eu odată greceşte".

Prodigios adolescent, ce nu mai era un copil - o rază de iubire sfioasă şi curată, pentru o fată de seama sa, îi încălzea inima, împingându-l la fapte de seamă, să ajungă la cinste şi să aibă bani, aur! Atunci nimic nu-i va mai sta piedică, va putea să-şi cumpere cărţi şi să înveţe, greceşte şi pe Homer! Dar cum?

America era pe atunci - aşa era vremea - ţara visurilor de cucerire a aurului şi într-acolo pleacă şi Schliemann, ca şi mai târziu, din cu totul alt mediu, dar în împrejurări şi chiar cu peripeţii mult asemănătoare, englezul Stanley. Schliemann, înspre America de Sud, aproape fără niciun ban, îşi vinde haina mai bună ca să-şi ia o pătură mai groasă şi, ca şi mai târziu englezul - cu aproape 20 de ani mai tânăr - angajat chipurile cu serviciul de băiat de vas, adevărată nenorocire pe care o descrie la vremea sa englezul. Schliemann are însă mai mult noroc. Vasul naufragiază în dreptul coastei olandeze. Pe vas, băiatul Schliemann nu lipsise să se ocupe, cât putea, cu limba spaniolă, dar avea să o înveţe şi pe cealaltă, a ţării unde cu adevărat soarta îl aruncase.

Schliemann stă în Olanda 4 ani, din 1842 până în 1846. Începe ca băiat de birou şi comisionar, însă jumătate din salariu îl cheltuia pentru studii. De-abia acum învaţă cum se cade să scrie şi să vorbească limba sa germană. Învaţă să scrie frumos, caligrafia, învaţă olandeza şi engleza, după o metodă practică a sa, dar îşi plăteşte ş̧i profesor. Cine dintre iubiţii noştri tineri de astăzi mă ascultă, să audă ce spune Schliemann: „La toate cursele mele, aveam cu mine, chiar când ploua, o carte în mână, din care învățam ceva pe de rost; la poştă nu aşteptam niciodată fără să citesc; aşa mi-am întărit încetul cu încetul memoria şi după trei luni, puteam să recitesc în fiecare zi cu uşurinţă, la ora de lecţie, în faţa profesorului, 20 de pagini tipărite de proză în limba engleză.

Învaţă franţuzeşte, apoi pe rând, spaniola, italiana şi portugheza, ca să le poată vorbi şi scrie curent.

La 22 de ani, corespondent şi contabil în marea casă de export Schröder \& Co., pune de la început în mirare pe patroni prin cunoaşterea a 7 limbi, aşa încât, în curând, dovedindu-se şi o minte foarte bună pentru negoț, ajunge să fie avansat în fiecare lună, fără consideraţia că e aşa de tânăr, şi ajunge să aibă 15 inşi în urma sa.

Trăieşte strict economiceşte şi trimite şi acasă. S-au păstrat şi micile sale conturi. Învaţă ruseşte, ceea ce-i deschide mai repede decât chiar a visat, drumul către împlinirea gândurilor lui vechi, aur, cinstire şi era vorba de o ţară încă puţin cercetată, unde cunoaşterea limbii avea să-i fie de un folos nebănuit. În scurtă vreme, scrie în ruseşte prima scrisoare unui agent din Londra a unei case de comerţ cu indigo din Moscova şi se înţelege în limba lor, cu negustori ruşi care veneau la exportatorii de indigo din Amsterdam.

La 24 de ani avea toate calităţile unui mare negustor, cu care îşi începe activitatea de la Petersburg, ca reprezentant, apoi ca asociat al firmei olandeze, mai târziu pe cont propriu, loc de care va fi legat 20 de ani, din 1846 până în 1866, când va lichida ca de multe ori milionar, ca să îndeplinească apoi ceea ce a fost visul vieţii lui, să înveţe şi să vadă ce este drept şi ce se poate dovedi din Homer şi Pausanias?

Pururi de o extremă acuitate şi probitate, el începe a călători des şi mult. Cheltuieşte însă totdeauna aceiaşi 50.000 de taleri imperiali. După 18 luni, se va întoarce în Rusia cu suma dublată. Aflându-se în California, deşi din întâmplare, capătă fără a cere, printr-o hotărâre luată pentru toţi, cetăţenia americană de care va şti să profite. Încă acolo fiind, scapă din focul ucigaş de la San Francisco din iunie 1851, el care înfruntase mai înainte două naufragii. Suit pe o colină în timpul focului, el îşi notează apoi impresiile de om încercat şi tare: „A fost o privelişte îngrozitoare, sublimă, într-adevăr cel mai minunat spectacol pe care l-am văzut vreodată". Puţine zile după aceea, deschide o bancă, pentru achiziţionarea de pulbere de aur. 
Dar cum munceşte? Tot din jurnalul său: „Mă scol totdeauna la 5 dimineaţa, o gustare la 5.30, deschid prăvălia la 6 şi o închid abia la orele 10 seara. Banca mea e de dimineaţă până noaptea înfundată de oameni din toate ţările şi trebuie să vorbesc ziua întreagă în 8 limbi”.

Aşa a izbutit şi a ajuns la aur. În 1852 Schliemann înfiinţase o filială a firmei sale, la Moscova. Dar are şi un noroc deosebit. În octombrie 1854, în timpul războiului Crimeii scapă ca prin minune de ruină. Două vapoare de marfă de la Amsterdam pentru Rusia, marfă depozitată la Memel, e singura care într-un loc ferit rămâne neatinsă dintr-un incendiu grozav, ca să-l îmbogăţească şi mai mult, cum singur o mărturiseşte.

În 1854 învaţă suedeza şi poloneza, în 1856 învaţă greceşte. „Recreerea mea - scrie surorii sale - sunt limbile, de care mă leagă o pasiune sălbatică. În timpul săptămânii sunt ce e drept neîntrerupt la contuar, însă duminica stau de dimineaţă până târziu seara cu Sofocle, pe care îl traduc în neogreacă”.

Împins ca de o putere nevăzută, se gândeşte la Mecklemburg, la Grecia, iarăşi la America sau la tropice şi scrie gândurile sale în greaca veche. S-au păstrat caietele lui. În acelaşi caiet, după gândurile de mai sus, urmează o compunere în limba neogreacă despre despărţirea lui Hector de Andromaca. Gândul la Grecia e tot mai aprins, dar aveau să treacă alţi ani - şi era încă tânăr - până să şi-l îndeplinească.

Între 1858-1859 învaţă latina, călătoreşte în Suedia, Italia, Egipt şi Atena. În 1863 lichidează firma şi părăseşte Rusia pentru totdeauna.

Între 1864-1865 face o călătorie în jurul lumii, prin India, China, Japonia şi înapoi prin America. Scoate prima lui carte „La Chine et le Japon”.

Din 1866 până în 1871 stă la Paris şi studiază arheologia, în legături cu cei mai de seamă învăţaţi francezi ai vremii.

Iată căutătorul de aur, în culmea puterii sale de om care a găsit ce căuta, în stare de a face mai mult chiar decât ceea ce încă din copilărie a visat şi a plâns. Care în această vreme scrie: „Ştiu că sunt zgârcit şi lacom. Trebuie să încetez de a mai fi aşa de lacom de bani. Tot timpul războiului (războiul Crimeii) numai la bani m-am gândit”.

„Duminica pot în sfârşit să mă recreez cu operele divinului Homer şi cu discursurile lui Demostene care făceau să ridice Acropolea".

„Ştiu, se zice: Cizmare, caută-ţi de calapoadele tale. Eu însă nu mai pot fi multă vreme negustor... La vârsta când alţii învăţau la liceu, eu eram un sclav şi abia la 20 de ani am ajuns la studiul limbilor. De aceea îmi lipseşte baza şi temeiul fundamental al învăţăturii. Un învăţat n-o să ajung niciodată, dar ceva, - vreau să repar. Dorinţ̧a mea este să studiez odată cum se cade şi speranţele mele cresc".

Speranţele lui s-au împlinit - şi acestea - cu prisosinţă, în a doua parte a vieţii sale care ţine încă 25 de ani. Cel ce a căutat şi găsit destul aur în prima parte a acestei vieţi, va ajunge să găsească tot aşa de mult, ba chiar şi de mai mare valoare - în pământ.

E căutătorul şi descoperitorul de aur de la Troia şi Mikene, năzuind până în Creta, unde însă alţii, şi printre aceştia mai ales chiar cel ce scrie prefaţa la cartea lui Emil Ludwig, englezul Sir Arthur Evans, vor avea norocul său de altădată.

\section{Arheologul Teohari Antonescu: 25 de ani de la moartea sa}

S-au împlinit anul acesta 25 de ani de la moartea Profesorului Teohari Antonescu de la Universitatea din Iaşi.

Era cel dintâi profesor de arheologie şi antichităţi la Facultatea de Litere a acelei Universităţi şi murea în vârstă de-abia de 44 de ani, neîmplinind nici două decenii de activitate profesorală, despre care a lăsat amintiri statornice printre colegii săi şi neuitate printre elevii ce i-a avut.

„- Ce facem cu concursul lui Teohari?”, scria Alexandru Odobescu lui Titu Maiorescu, la 25 Octombrie 1895. E vremea în care Teohari Antonescu, născut la Giurgiu în 1866, a ocupat catedra de la Iaşi, nou înfiinţată.

Elev dintre cei mai aleşi al lui Alexandru Odobescu, Teohari Antonescu se distinsese în chip deosebit încă din 1889, cu o teză de licenţă, mai amplă şi mai nouă decât cele mai multe de pe vremea sa, despre „Cultul Cabirilor în Dacia”, dedicată lui Odobescu, 9 ani după apariţia lucrării şi mai vaste a lui Grigore Tocilescu „Dacia înainte de Romani”, al cărei autor era însă mai mare cu 16 ani decât celălalt. E bine să se menţioneze că dacă „Dacia înainte de Romani” a fost reluată nu mulţi ani după moartea autorului ei, culminând cu „Getica” lui Vasile Pârvan din 1927, în ce priveşte tema de debut a arheologului Teohari Antonescu „Cultul Cabirilor în Dacia”, de-abia astăzi aşteptăm să se ajungă la o tratare corespunzătoare cu ce se ştia în vremea de faţă despre acest cult al divinităţilor orientale 
numite Cabiri, atât în Dacia, cât şi în Europa sud-estică. Va fi lucrarea unui distins profesor tânăr, cercetător al antichităţilor din Oltenia, Dl. Dimitrie Tudor.

Acum 25 de ani, într-o aspră zi de Ianuarie, Teohari Antonescu era condus de familie, de colegi, de studenţi şi prieteni la „Eternitatea” din Iaşi. La biserica Sf. Spiridon 1-a slăvit în impresionante cuvinte despre legătura iubitoare dintre arheolog şi pământul care-l aşteaptă, după ce l-a cercetat îndelung şi a vrut să-i smulgă tainele, - dl. I. Petrovici, atunci tânăr conferențiar la Universitate; 1-au plâns elevii săi în revista „Arhiva” şi gazetele locale. De la Bucureşti a răsunat în „Neamul Românesc Literar" cuvântul unui fost coleg de-al său, Dl. N. Iorga, care încheia: „Se duce încă tânăr... Nu fără un zâmbet în urmă a intrat sufletul lui în luntrea ce trece peste apele râului de uitare”.

Se cuvine deci să ne aducem aminte cine a fost şi ce a lucrat acest profesor şi arheolog, cel dintâi la una dintre Universită̌ţile noastre şi printre foarte puţinii specialişti pe acea vreme, într-un domeniu totuşi aşa de însemnat cum netăgăduit este viaţa veche şi străveche a Daciei şi a lumii.

Teohari Antonescu n-a scris mult şi spre deosebire de profesorul său Alexandru Odobescu ca şi de înaintaşul său Grigore Tocilescu, nu s-a dispensat în prea multe direcţii, chiar ale specialităţii sale. $\mathrm{Cu}$ antichităţile mai noi s-a ocupat numai foarte puţin şi incidental.

Aşa i-a fost firea şi poate aşa îşi simţea puterile. Desigur însă şi şcoala mai nouă l-a făcut să fie aşa: şcoala lui Adolph Furtwängler de la Munchen şi Collingnon de la Paris, călătoriile sale în țările clasice, semnul în care sta arheologia pe vremea sa, după faimoasele descoperiri ale lui Schliemann de la Troia, continuarea şi reluarea lor de către Dörpfeld şi colaboratorii săi, unii dintre aceştia contemporani şi poate colegi de-ai săi. Curentul nou de extensiune a studiilor clasice înapoi în legătură cu trecutul preclasic şi preistoric îl va fi prins în vâltoarea sa şi pe tânărul arheolog român, în vremea studiilor şi călătoriilor sale. Paralel cu studiile sale de arheologie clasică, aşa precum se concepeau de la Alexandru Conze, Teohari Antonescu s-a interesat îndeaproape - şi aceasta o dovedesc cursurile sale - şi de arheologia preclasică, preistorică, ajungând a fi perfect informat, dovadă un mare număr de cărţi din biblioteca sa, citite de dânsul cu atenţie şi cu însemnări, dintre cele mai fundamentale cărţi ale vremii de această specialitate, ca de pildă „Die neolithische Station von Butmir” de Hoernes, Radinsky şi Fiala, lucrări achiziţionate şi studiate atent desigur îndată după apariție. Unele dintre acestea au fost cumpărate după moartea sa de Muzeul Naţional de Antichităţ̧i şi Seminarul de Istorie Antică de la Universitatea din Bucureşti.

Aşa se explică că dacă, de pildă, în ce priveşte activitatea sa ştiinţifică în scris, Teohari Antonescu publică mult mai puţin, în „Convorbiri Literare” din 1895: Descoperirile de la Troia şi Dacia - patria primitivă a popoarelor ariene, în 1901 - Cum s-a format preistoria, în 1902 - Originile omului, - cursul său de arheologie din 1906 şi de preistorie din 1907 sunt de cea mai largă şi completă informaţie: arheologie generală clasică (1906), preistorie (1907), tot 1907 Ceramică greacă, cu ample prezentări şi documentare a stilurilor şi mitologiei ca izvor de inspiraţie plastică. Nu au lipsit în alţi ani nici cursuri de arhitectură şi plastică antică, după planşe şi diapozitive. La foarte puţine universităţi se făceau asemenea cursuri în ciclu deplin, de la Paleolitic şi până la manifestările cele mai de seamă ale artei medievale, bizantine, romanice şi gotice. În aceasta Teohari Antonescu se silea să urmeze pe maestrul său Odobescu, fiind de un nepreţuit ajutor ascultătorilor săi.

Teohari Antonescu a fost un profesor atât de conştiincios încât, un timp, trebuind a suplini pe colegul său de istorie veche, regretatul Petre Râşcanu, cât acesta avea anumite însărcinări oficiale, nu a făcut numai cursul acestuia, ci deşi fără nicio pretenţie de a fi orientalist, a adâncit, ba chiar a şi publicat câteva din problemele civilizaţiei Orientului ce l-au atras mai mult: 1897 - Originea Egiptenilor, 1898 - Epopeea lui Izdubar şi Din lumea chaldee, 1899 - Filozofia Upanişadelor, 1901 - Din literatura egipteană, 1903 - Budhismul şi Nirvana.

Unele dintre aceste studii, Teohari Antonescu le-a publicat la un loc în frumoasa carte, aşa de vrednică de a fi citită şi astăzi: „Lumi uitate”, studii literare şi arheologice, Iaşi, 1901.

Îngăduiţi un singur fragment din Epopeea lui Izdubar, de mitică tradiţie, asemenea cu epopeea homerică, dar de cu totul alt spirit, al unei alte lumi, Chaldeea ţinuturilor de la Ur, Uruk, Larsa, etc. Într-o tăbliţă cuneiformă, eroul Izdubar cere cu violenţă zeului morţii să-i scoată la lumină sufletul lui Eabani.

„În faţa acestei umbre scumpe”, zice Teohari Antonescu, ,umbre îmbrăcate în giulgiul său de moarte, Izdubar apucat de setea de a cunoaşte ce este dincolo de groapă, întreabă vedenia ce stă înainte-i” - şi Antonescu traduce după o versiune modernă dar aproape în metru antic:

- Spune-mi prietene, spune-mi, prietene, spune-mi

Ce fel e locaşul unde-ai umblat, o spune-mi!

- Nu pot să-ţi spun tovarăşe, nu pot să-ţi spun tovarăşe,

Căci de-aş vrea să-ţi spun ce fel e locaşul 
Ar trebui să te aşterni în ţărână şi să plângi

- Mă voi aşterne în ţărână şi voi plânge

- Ascultă. Tot ce-ai făcut pe pământ e zadarnic

Şi tot ce-a mângâiat sufletul tău, o himeră

Întocmai ca pe un veşmânt învechit, viermii trupul ţi-1 rod.

Tot ce-ai făcut pe pământ e zadarnic

Şi tot ce-a mângâiat sufletul tău, o himeră,

Căci praf şi țărână se aşează pe tine.

Alexandru Odobescu fusese prozatorul-creator, de mari resurse şi de o neobişnuit de bogată putere de expresie învietoare. Dintr-o a treia generaţie, Vasile Pârvan va fi filozoful chinuit de sensul şi resorturile adânci ale vieţii. Fie-mi permis a crede că şi Teohari Antonescu, apropiindu-se cu sufletul în vibraţie de vechi lumi uitate şi încercând a le învia, nu a făcut-o numai gândindu-se la maestrul său Odobescu, cu care cumva se silea numai să-i semene.

În acelaşi volum din „Lumi uitate”, arheologul Teohari Antonescu, publică şi un studiu tot aşa de special şi de caracteristic ca şi acela „Cum s-a format preistoria” şi anume: „Un veac de cercetări arheologice”, apărut întâi în „Omagiu lui Titu Maiorescu”, 1900, pag. 169.

Deopotrivă de bogate în fapte şi caracterizări, amândouă studiile mai sunt în plus o dovadă, cu câtă justeţe, largă înţelegere şi adevărate însuşiri de precursor înţelegea Teohari Antonescu ştiinţa sa, mai ales la noi.

Despre aceasta ne putem da seama mai bine comparând paginile sale cu acelea ale conferinţei arheologului german contemporan cu dânsul Adolph Michaelis, exact cu aceeaşi temă - „Die archäologischen Entdeckungen des XIX an Jahrhunderts", lucrarea acestuia este însă din 1904-1905 şi încă şi mai târziu s-a transformat în cuprinzătoarea carte din 1908: „Ein Jarhundert kunstarchäologischer Entdeckungen” (Un veac de cercetări arheologice).

Să compare cineva şi să judece. În esenţă, nicio distonanţă, nimic uitat, nici chiar accentul pe aşa-zisa „Archäologie des Spatens", - arheologia de hârleţ, de târnăcop, de săpături, care evident preocupă şi mai mult pe arheologul german.

„Scena lumii” - zice Teohari Antonescu - ,a fost lărgită în spaţiu, dar mai ales lărgită în timp. De unde până mai ieri, nu se cunoşteau decât popoarele din preajma Mării Mediterane, astăzi, mulţumită cercetărilor din veacul trecut, cunoaştem lunga desfăşurare de viaţă a popoarelor de la Nil şi din Mesopotamia. Pe de altă parte, originile neamului omenesc au fost mai de aproape studiate şi istoricul astăzi poate să urmărească cu amănuntul paşii acelui om cuaternar, care, sau pribegea după animale de-a lungul apelor şi prin păduri, sau se adăpostea de suflările îngheţate ale vânturilor prin scorburile copacilor sau prin speluncile munţilor”. „Şi numai cercetărilor Arheologiei datoreşte istoria aceste rezultate strălucite”.

Ceea ce Odobescu bănuia numai cu două decenii în urmă, Teohari Antonescu confirmă şi întregeşte. De aceea şi citează, cred, tocmai paleoliticul, căci despre celelalte timpuri posterioare vorbise şi Odobescu cu ce se putea şti pe vremea sa.

Ultimii ani, Teohari Antonescu publică în 1905 - Le Trophée d’Adamclisi, Étude archéologique, făcând sforţări remarcabile ca să stabilească o nouă orânduire a metodelor ce împodobeau corpul cilindric al marelui monument, studiat mai înainte de Benndorf şi Tocilescu, Niemann şi Furtwändgler. A ajuns Teohari Antonescu la rezultate definitive sau numai la alte simple ipoteze? Cine ar putea s-o spună? Cu excepţia unui cercetător german, care s-a ocupat în treacăt cu monumentul, în timpul războiului, nimeni nu s-a mai oprit la formidabilele ruine, pentru cercetarea cărora se cer însemnate mijloace, ba, cu excepţia unei singure metope care a fost aşezată la loc de cinste în Muzeul Naţional de Antichităţi, celelalte stau tot expuse în ploaie şi zăpadă, cum erau acum 25 de ani. Ce au visat, fiecare deosebit, Tocilescu şi Antonescu, de-abia de acum înainte se va putea împlini. Deocamdată, la Tropaeum Traiani, în vale de culmea strălucitului monument al romanismului din Europa sud-estică, după săpăturile lui Tocilescu şi ale d-lui Prof. Murnu, s-au reluat recent deşi cu mijloace minime, cercetările începute: sunt lucrările din ultimii ani ale D-lui Paul Nicorescu de la Universitatea din Iaşi.

În 1906, cu ocazia marii expoziţii naţionale, Teohari Antonescu s-a silit să colaboreze cu ce credea că poate mai bine: „Cetatea Sarmizegetusa reconstituită”, Iaşi 1906, şi - ajutat de doi tineri artişti, Antonescu a întocmit chiar o machetă de reconstituire plastică care există, păstrată la Muzeul Militar Naţional. E vorba de vechea Ulpia Traiană, de la Grădiştea Hunedoarei. Au fost şi zâmbete: de unde să ştie Teohari Antonescu cum a fost Sarmizegetusa, numai după arătările Columnei Traiane şi călătoriile sale pe vechile drumuri şi pe la vechile ruine nedesfundate. Ce făcuseră sau au vrut să facă Ungurii pe locurile falnicei capitale a Daciei romane era cu mult prea puţin, ca şi nimic: nu-i lega nimic. După ce s-au petrecut atâtea în ultimii 25 de ani, noi vedem în încercarea să-i zicem temerară 
sau romantică a arheologului Teohari Antonescu un semnificativ gest prevestitor de conştiinţă naţională pe care-1 putea aduce un om de specialitatea sa, slujindu-se de mijloacele de informaţie ale vremii, de câtă ştiinţă, instinct şi viziune putea să aibă. Aceasta e cu atât mai adevărată, cu cât de-abia astăzi ştim mai mult şi s-au găsit lucruri cu totul remarcabile şi adânc impresionante din viaţa cetăţilor dacice şi a mândrei Ulpii Traiane. Cercetătorii arheologi sunt D-nii D.M. Teodorescu şi Constantin Daicovici de la Universitatea din Cluj. Mijloacele: iubirea de trecut şi adânc înţelegătoarea munificenţă regală, asigurând chiar viitorul: anul acesta, însuşi Moştenitorul Tronului a dus la locul sfinţit de amintirea Regelui Decebal şi a Împăratului Traian, banii trebuincioşi pentru săpături. Niciun arheolog şi niciun istoric nu putea să viseze mai mult acum 30 de ani pentru cercetarea acestui trecut.

În sfârşit, ultima lucrare a lui Teohari Antonescu este: „Columna Traiană”, studiată din punct de vedere arheologic, geografic şi artistic, vol. I, operă apărută după moartea sa în chiar acelaşi an 1910, cu rânduri de prefaţă scrise „cu durere în suflet” de marele istoric Alexandru Xenopol. Operă compactă, îndelung pregătită, scrisă cu aceeaşi îngrijire de formă a întreg scrisului său. E identificarea basoreliefurilor de pe Columna lui Traian, cu localităţile actuale ce au păstrat în ruină rămăşiţe din viaţa de odinioară a Dacilor şi a Romanilor.

Şi iarăşi aceeaşi piedică, aceeaşi lipsă a săpăturilor nu îngăduie un cuvânt mai hotărâtor de confirmare a laborioaselor cercetări întreprinse de arheologul nostru. După el cercetarea a fost reluată, până acum potrivit cu cerinţele noi, adică prin săpături, în două singure puncte: la Tibiscum, de către regretatul arheolog Gheorghe Mateescu, elev al lui Vasile Pârvan, întâmplător din acelaşi loc de naştere ca şi înaintaşul său Teohari Antonescu; recent, tot în Banat s-au făcut cu mijloace locale săpături şi cercetări de către D-nii Scarlat Lambrino şi Grigore Florescu de la Universitatea din Bucureşti. Dar ce înseamnă aceste singure puncte din tot parcursul oştilor romane şi mulţimea aşezărilor lor? Nădejdea în viitor, la care desigur şi Teohari Antonescu s-a gândit.

Iată cine a fost acela de la a cărui plecare dintre noi s-au împlinit 25 de ani. Prin ce a făcut, el nu poate fi uitat şi atunci când, recent, în deplină înţelegere şi continuitate, fruntaşii intelectuali ai locului său de naştere - Giurgiul - D-nii Alexandru Cartojan, Anghel Rădulescu şi Savin Popescu, directorul liceului, înfiinţând cu multă grijă şi cheltuială un muzeu şi începând o publicaţie a acestuia, i-au dat numele „Teohari Antonescu”, au făcut cea mai frumoasă faptă ce se putea face în acest an de aducere-aminte a morţii sale, după o viaţă de muncă, prea repede frântă şi de visuri nobile ce rămân de împlinit.

\section{BIBLIOGRAFIE}

Andrieșescu 1910

Andrieșescu 1912

Andrieșescu 1920

Andrieșescu 1935

Andrieșescu 1939

Condurachi 1943

Denize 1998

Ludwig 1932
Andrieșescu, I., Teohari Antonescu, Arhiva. Organul Societății științifice și literare din Iași, an XXI, nr. 1, ianuarie 1910, 46-48.

Andrieșescu, I., Contribuție la Dacia înainte de Romani, Institutul de Arte Grafice N.V. Ştefăniu\&Co., Iaşi, 1912, 124 p.

Andrieşescu, I., Câteva consideraţiuni şi îndemnuri de început cu privire la Istoria veche şi ştiinţele ei ajutătoare. $\mathrm{Cu}$ o introducere despre Petru Răşcanu şi Teohari Antonescu - O lecţie de deschidere, Revista Istorică, VI, nr. 3-6, 1920, 95-115; nr. 7-9, 136-162.

Andrieșescu, I., Teohari Antonescu, Buletinul Muzeului Judeţului Vlaşca „, Teohari Antonescu”, I, 1935, 57-59.

Andrieșescu, I., Artele în timpurile preistorice la noi, Artă şi Tehnică grafică, 4-5, 1938-1939, 25-50.

Condurachi, E., Teohari Antonescu şi originile poporului român, emisiunea Universitatea Radio, ciclul „Arheologii noștri și originea neamului românesc”, 16 iunie, ora 20,40, Arhiva Societății Române de Radiodifuziune, dosar nr. 10/1943, 6 file, mss.

Denize, Eugen, Istoria Societăţii Române de Radiodifuziune, vol. 1, partea întâi (1928-1937), București, 1998.

Ludwig, Emil, Schliemann: Geschichte eines Goldsuchers, Berlin, 1932. 
Mușețeanu 1998

Nicolae 2011

Petrescu-Dîmbovița 2005

Popovici 2000

Tocilescu 1880
Mușețeanu, L. (coord.), Bibliografie radiofonică românească (1928-1935), vol. I, București.

Nicolae, C. I., Arheologi și arheologie în emisiunile radioului public (19301944), in D. Măgureanu, D. Măndescu, S. Matei (eds.), Archaeology: making of and practice. Studies in honor of Mircea Babeș at his $70^{\text {th }}$ anniversary, Pitești, 2011, 67-85.

Petrescu-Dîmbovița, M., Profesorul Ioan Andrieșescu. Omul și opera, Codrul Cosminului, 11, 2005, 223-233.

Popovici, D.-N., Note pentru o viitoare și necesară istoriografie a arheologiei românești (I), Buletinul Muzeului ,, Teohari Antonescu”, V-VI, 1999-2000, 17-22.

Tocilescu, Gr., Dacia înainte de romani. Cercetare asupra poporului care a locuit Țările Române de la stânga Dunării, mai înainte de conquista acestor țări de contra Imperiului Traian, Tipografia Academiei Române, București, 1880.

\section{LIST OF ILLUSTRATIONS}

Figure 1. Last page of the conference manuscript Praehistoric arts in Romania (I), Archive of the "Vasile Pârvan" Institute of Archaeology, Andrieșescu files.

Figure 2. The stamp of the Romanian Radio-Broadcasting Society (RRS) on the first page of the manuscript of the conference New archaeological discoveries, RRS Archive, file no. 14/1933, page 1.

CĂTĂLIN I. NICOLAE, Institutul de Arheologie „Vasile Pârvan”, nicotk@gmail.com 